\title{
Drivers of Proactive Environmental Strategies: Evidence from the Pharmaceutical Industry of Asian Economies
}

\author{
Rizwan Raheem Ahmed $^{1}{ }^{(\mathbb{D}}$, Grigorios L. Kyriakopoulos ${ }^{2} \mathbb{D}$, Dalia Streimikiene ${ }^{3, *(D)}$ and Justas Streimikis ${ }^{3,4}$ \\ 1 Faculty of Management Sciences, Indus University, Gulshan-17, Karachi 75300, Pakistan; \\ rizwanraheemahmed@gmail.com \\ 2 School of Electrical and Computer Engineering, Electric Power Division, Photometry Laboratory, National \\ Technical University of Athens, 9 Heroon Polytechniou Street, 15780 Athens, Greece; \\ gregkyr@chemeng.ntua.gr \\ 3 Lithuanian Centre for Social Sciences, Institute of Economics and Rural Development, A. Vivulskio g. 4A-13, \\ LT-03220 Vilnius, Lithuania; justas.streimikis@gmail.com \\ 4 Faculty of Management and Finances, University of Economics and Human Science in Warsaw, \\ 01-043 Warsaw, Poland \\ * Correspondence: dalia.streimikiene@lei.lt; Tel.: +37-0-6140-3424
}

check for

updates

Citation: Ahmed, R.R.;

Kyriakopoulos, G.L.; Streimikiene, D.; Streimikis, J. Drivers of Proactive

Environmental Strategies: Evidence from the Pharmaceutical Industry of Asian Economies. Sustainability 2021, 13, 9479. https://doi.org/10.3390/ su13169479

Academic Editors: Roberta Costa and Mohammad Valipour

Received: 29 July 2021

Accepted: 18 August 2021

Published: 23 August 2021

Publisher's Note: MDPI stays neutral with regard to jurisdictional claims in published maps and institutional affiliations.

Copyright: (c) 2021 by the authors. Licensee MDPI, Basel, Switzerland. This article is an open access article distributed under the terms and conditions of the Creative Commons Attribution (CC BY) license (https:// creativecommons.org/licenses/by/ $4.0 /)$.

\begin{abstract}
The objective of the undertaken study is to investigate the association between proactive environmental strategy (PES) and its determinants, such as planning and organizational practices (POP) and communicational practices on sustainable development through the operating and financial performances of the pharmaceutical sectors of south Asian countries. Moreover, we examine this relationship through the eco-innovations as a meditator and technological advances as a moderator. We developed a modified conceptual model and questionnaire and verified by 856 responses from the region's pharmaceutical sectors. We have tested our hypothesized research model and hypotheses through SEM-based modeling. The findings confirm that proactive environmental strategy and its determinants, for instance, organization and planning practices, operating practices, and communicational practices, have a positive and significant influence on pharmaceutical firms sustainable development through operational and financial performance. The findings further show the substantial role in eco-innovation as a mediator and technological advances as a moderator on the sustainable development in this relationship. Subsequently, eco-innovation and technological advances lessen ecological hazards and increase companies' functioning. Therefore, the undertaken study demonstrated and concurrently ascertained towards sustainable development of environmental and economic leaders. The practical implications are equally important for every stakeholder, such as the community, policymakers, companies, and regulatory agencies concerned with fostering eco-friendly controlling exercises.
\end{abstract}

Keywords: proactive environmental strategy; eco-innovation; technological advances; sustainable development; operational performance; financial performance; planning and organizational practices

JEL Classification: C12; M14; Q2

\section{Introduction}

The most pressing challenge of today's society is to attain a sustainable environment for future generations to live better [1-3]. Thus, companies are also susceptible to environmental hazards due to social pressure and employing diverse initiatives to minimize these environmental hazards [4,5]. According to Genç and Benedetto [6] and Hart and Ahuja [7], the previous literature demonstrates the awareness and importance of environmental protection, and highlights several imperative variables for the companies' green environment. According to Vithessonthi [8] and Quazi et al. [9], several pieces of research have advocated the prominence of distinctive determinants for proactive environmental 
strategies, for instance, planning and operating practices (POP) and communicational practices (CP). Society and industry should solve the protection of environmental issues; thus, companies have a vital role in saving the natural environment for the community $[10,11]$. Hence, global warming and other environmental issues have become pertinent factors for existing competitive circumstances on a globalized planet [12]. The eco-friendly approach is described as "to preserve the edge between the natural environment and industrial progress" (Aragon-Correa and Sharma [13], p. 7). The companies concerned with alleviating their collision in the natural environment should know the realistic inferences of environmental hazards management. Several researchers have addressed this critical issue, such as Hunt and Auster [5], Seroka-Stolka and Fijorek [14], and Min and Oh [15]. They have differentiated the proactive companies for managing the environment rather than reactive towards the environmental hazards. According to Forés [4], Hunt, and Auster [5], if the organization devises and implements environmental protection initiatives with its motivation, it is a proactive environmental strategy. The self-motivated environmental precautions are free from any regulations. The proactive environmental protection strategies include preserving waste material and reducing energy, emissions, hazardous material, and chemical wastes regarding processes and products $[12,16]$. However, at the same time, the implementation of environment-related regulations to protect the ecosystem and community from pollution and smog is regarded as eco-friendly reactivity [17]. The reactive strategy involves implementing minimal essential alterations to meet rules and laws to employ the smog controls to prevent penalties and bad reputation $[18,19]$.

Proactive environmental practices have been debated for a long time regarding the dimensions and aspects. Some researchers have argued that the proactive environmental strategy (PES) is one-dimensional [4,20,21]. However, Lucas [22] and González-Benito and González-Benito [23] have a different opinion, and they established that a proactive environmental strategy has multi-dimensional aspects. Hence, three reasonable practices are included in a proactive environmental strategy in which organizing and planning practices are the most important [24]. This practice involves the allocation of resources, devising strategies, and the development of environmental policies and procedures. However, the second practice comprises operational practices, which involve implementing devised environmental responsibilities and practices. The third is known as the communicational practices, which are involved throughout the implementation process to track the practices in the right direction $[25,26]$. Ecofriendly companies are more competitive due to the proactive approach to environmental hazards $[4,6]$. Recent studies are reinvestigating, not only the factors which have remained eco-friendly, but how and with whose efforts these companies remain eco-friendly [27-30]. As such studies' findings are not conclusive, the debate is still open vis à vis focusing on the eco-friendly concerns. Additionally, current research outcomes demonstrated that the association is not direct between companies' performance and execution of volunteer eco-friendly exercises [2,31,32]. According to Do and Nguyen [33], Hoang et al. [34], and Cheng et al. [35], the association between environmental strategies and companies' performance is meditated through some prominent factors. Thus, the reinvestigation of this association has become very vital. Hence, the research has addressed the mediation and moderation association, evaluated the novel modified conceptual framework, and examined the company's performance, taking proactive environmental strategy as an independent variable and eco-innovation as a mediator and technological advances as moderator $[25,36,37]$.

\subsection{The Novelty and Significance of the Research Study}

The novelty and significance of this research are embedded in a unique and modified conceptual framework and questionnaire that can be replicated by future researchers for other industries. Additionally, this is the first kind of study that addresses the environmental concerns of Asian pharmaceutical sectors, which will benefit the practitioners and senior managers to reduce the intensity of environmental hazards for consistent operational and financial performance. This research also introduces three different statistical techniques 
for analyzing the data. Thus, this unique modeling will be helpful for future researchers and industry practitioners. Therefore, the research has imperative theoretical implications for providing new knowledge amid determinants of proactive environmental, mediator, and moderator in a modified conceptual framework for future investigations. On the other hand, the findings also contributed to the practical implications of providing green business strategies for operating and financial performance in the pharmaceutical industry. Additionally, this research's findings offer guidelines to the policymakers, companies, communities, and regulatory bodies regarding practices of environmental exercises.

\subsection{The Objectives of the Research Study}

The research evaluates the direct effect of proactive environmental strategy and its determinants, such as organization and planning practices, operating practices, and communicational practices, on pharmaceutical firms' financial and operational organizational functioning. Moreover, the indirect (mediation) effects of eco-innovation and moderation of technological advances between proactive environmental strategies and its determinants, and financial and operational performances, have been analyzed in the context of pharmaceutical sectors of China and south Asian countries, for instance, China, India, Pakistan, Bangladesh, and Sri Lanka. This research proves that proactive environmental strategies and their determinants, technological advances, and eco-innovation concurrently positively contribute to the companies' eco-friendly aspects and sustainable development. This research's prime objective is to evaluate the scope of independent variables, mediators, and moderators on the operational and financial performance of the pharmaceutical sector of Asian economies.

\subsection{Research Questions of the Undertaken Study}

We have addressed the following questions to fulfill the objectives of the research study:

Are proactive environmental strategies, such as organization and planning practices, improving the financial and operational functions of pharmaceutical sectors of south Asian countries?

Are proactive environmental strategies, for instance, operating practices, improving the financial and operational functions of the pharmaceutical sector?

Are proactive environmental strategies, for instance, communicational practices, improving the financial and operational functions of the pharmaceutical sector?

Is eco-innovation (mediator) an efficient and effective strategy to improve the financial and operational practices of the pharmaceutical industry?

Are technological advances (moderator) improving environmental hazards for the pharmaceutical industry's long-term financial and operational performance?

The remaining paper is structured as follows: section two contains the theoretical framework and hypotheses development; section three comprises of the materials and methods of the study; section four analyzes the data and provides the findings of the study; section five contains discussions; and section six provides conclusions, and followed by theoretical and practical implications, and limitations and areas of future studies.

\section{Theoretical Framework and Hypotheses Development}

\subsection{Theory Underpinning-Resource-Based View Theory}

Deutz and Ioppolo [38] and Bansal and Roth [39] state that a proactive environment strategy uses distinctive theoretical perceptions. However, some research studies employ institutional theory in a proactive environmental approach. Buysse and Verbeke [20] and Henriques and Sadorsky [21] have incorporated stakeholder theory. However, several researchers used the organization's resource-based view to adopt the proactive environmental strategy, including a dynamic competency viewpoint [13,40-42]. The proactive environmental strategy and organizational performance have a strong association; thus, the resource-based view method is helpful to evaluate this bond. Therefore, the undertaken study has examined the link between proactive environmental strategy and 
organizational performance. We have also taken into account the different theoretical backdrop to investigate eco-innovation. The co-evolutionary and neoclassical techniques from evolutionary theory on innovation [16,43] and innovation economics to environmental economics [44] have demonstrated eco-innovation. According to Do and Nguyen [33] and Rehfeld et al. [45], several studies have used general innovation theory to explain eco-innovation, and it was further extended to become the environmental innovation theory [46]. Afterwards, several researchers have used this approach [47]. Previous literature has employed stakeholder theory $[28,48]$, neo-classical, and institutional theories $[49,50]$. However, limited literature is available on eco-innovation, which cites the resource-based view [51]. According to Bluemling et al. [1] and Del Rio et al. [52], the complex role of an organization's internal elements, such as dynamic competencies and resource capabilities, is understated in previous literature regarding the eco-innovation process. Therefore, we have employed this theory in our research. According to the eco-economics scoreboard, south Asian economies are among the worst countries which have used the concept of eco-innovation in the industry for better organizational and financial performance. In this situation, eco-innovations initial objective inclines and relies on technological advances, including processes and products as eco-innovation aims. Due to this reason, we have included technological advances as a moderator with eco-innovation as a mediator to examine the business performance of an organization.

\subsection{Proactive Environmental Strategy and Organizational Performance}

The previous literature has demonstrated the various corporate environmental approaches and companies' continuum, ranging from reactive to proactive or the other way around. Hunt and Auster [5] have differentiated proactive companies for managing the environment rather than reactive towards environmental hazards. According to Sturiale et al. [53] and Yarahmadi and Higgins [54], if the organization devises and implements environmental protection initiatives with its motivation, it is known as the proactive environmental strategy. These self-motivated environmental precautions are free from any regulations. These proactive environmental protection strategies include preserving waste material, reducing energy, smoke, hazardous material, and chemical wastes regarding processes and products $[12,14]$. However, at the same time, the implementation of environment-related regulations to protect the environment and community from pollution and smog is regarded as environmental reactivity $[17,36]$. The reactive strategy involves implementing minimal essential alterations to meet rules and laws to employ the smog controls to prevent penalties and bad reputation [19,31,55]. According to Liu and Shu [28], Hart [42], and Menguc and Ozanne [56], the natural resource-based view of an organization, the proactive environment strategy, offers the cumulative abilities and resources to secure environmental deprivation through environmentally friendly technologies, processes, and products. The proactive environmental strategy has several benefits to the organization; it provides a proactive approach to align strategic direction according to the changing needs, allowing an organization to remain competitive and achieve long-term sustainable growth and development. Thus, the proactive environmental strategy has a significant influence on the organization's operational performance $[12,33,34,57]$. Thus, we framed the following hypothesis:

H1A. Proactive environmental strategy has a positive and significant impact on the operational performance of an organization.

According to the organization, the competitive advantage increases the organizational profitability and financial performance; a proactive environmental strategy significantly reduces the environmental hazards, wastes, pollution, and energy consumption, and increases operational performance $[12,33,58]$, which also have a positive impact on the financial performance of an organization. Other researchers have also found a positive relationship between proactive environmental strategy and financial performance $[12,23,25,58]$. Thus, we have framed the following hypotheses: 
H1B. Proactive environmental strategy has a positive and significant impact on the financial performance of an organization.

\subsection{Determinants of Proactive Environmental Strategy and Organizational Performance}

The previous literature has demonstrated the various corporate environmental approaches and companies' continuum ranging from reactive to proactive or the other way around. Hunt and Auster [5] and Koirala and Pradhan [25] have differentiated proactive companies for managing the environment rather than reactive towards environmental hazards. However, at the same time, the implementation of environment-related regulations to protect the environment and community from pollution and smog is regarded as environmental reactivity [17]. The reactive strategy involves implementing minimal essential alterations to meet rules and laws to employ the smog controls to prevent penalties and bad reputation [2,19]. According to Hunt and Auster [5] and Hsiao and Wang [36], if the organization devises and implements environmental protection initiatives with its motivation, it is a proactive environmental strategy. The proactive environmental protection strategies include preserving waste material, reducing energy, smoke, hazardous material, and chemical wastes regarding processes and products [12,18]. Thus, organizational practices [5,12,25], planning and organizational practices [5,15,36], and communicational practices $[12,18,36]$ have a significant and affirmative influence on operational performance $[5,12,18,25,36]$. Hence, we framed the following hypotheses:

H2. Operational practices have a significant and affirmative influence on the operational performance of an organization.

H3. Planning and organizational practices have a significant and affirmative influence on the operational performance of an organization.

H4. Communicational practices have a significant and affirmative influence on the operational performance of an organization.

Proactive environmental practices are debated for an extended period regarding the dimensions and aspects. Some researchers have argued that the proactive environmental strategy is one-dimensional $[20,21,59]$. However, others have a different opinion, and they established that a proactive environmental strategy has multi-dimensional aspects [22,23]. Therefore, according to Do and Nguyen [33] and González-Benito and González-Benito [24], three reasonable practices are included in a proactive environmental strategy in which planning and organizational practices are the most important. This practice involves the allocation of resources, devising strategies, and the development of environmental policies and procedures. However, the second practice comprises operational practices, which apply in the implementation of devised environmental responsibilities and practices. The third is known as the communicational practices, which are involved throughout the implementation process to track the patterns in the right direction. Hence, the previous literature also exhibited that the proactive environmental strategies [22,24,33,53] and operational practices $[12,33,59]$ have a significant impact on the financial performance of an organization [26,59]. Similarly, planning and organizational practices $[17,20,21]$ and communicational practices $[20,23,24]$ positively and cogently impact financial performance. Thus, based on the previous literature, we have framed the following hypotheses:

H5. Operational practices have a significant and affirmative influence on financial performance.

H6. Planning and organizational practices have a significant and affirmative influence on financial performance.

H7. Communicational practices have a significant and affirmative influence on financial performance. 


\subsection{Inter-Reliant on Firm's Performance}

Numerous works of literature have demonstrated that a firm's operational performance depends on financial performance, and several studies have evaluated operational and financial performance separately [2,23]. Moreover, according to Cheng et al. [35] and Chi and Gursoy [60], the firm's performance measures are inter-reliant in operational and financial performance. Thus, we have framed the following hypothesis:

H8. A firm's operational performance has a significant and affirmative influence on financial performance.

\subsection{Eco-Innovation as a Mediator}

Fussler and James [61] have proposed the initial definition and concept of ecoinnovation; according to them, it is evolving new processes, new products that offer business and customer value by reducing environmental hazards. According to Wahyudin and Malik [10], Liu and Shu [28], Do and Nguyen [33], Ciasullo et al. [62], and Kemp and Pearson [63] the eco-innovation is the creation and assimilation of a production process, product, service, business, or management technique throughout its life cycle, which is unique for the company and reduces environmental hazards, smog, energy, or other harmful effects of resources. The European Commission [64] has described eco-innovation as "eco-innovation as any form of innovation resulting in or aiming at significant and demonstrable progress towards the goal of sustainable development, through reducing impacts on the environment, enhancing resilience to environmental pressures, or achieving a more efficient and responsible use of natural resources." However, Genç and Benedetto [6] and Blanco et al. [30] show no direct association between companies' eco-friendly strategies and operating and financial performances. Similarly, Molina-Azorín et al. [29], Son et al. [31], and Hsiao and Wang [36] have established that a green environment and organizational performance have an indirect relationship. Thus, it may be interesting to measure the indirect causal relationship of eco-innovation as a mediator between proactive environmental strategies and companies' operational and financial performance. Several researchers have demonstrated that eco-innovation is a potent mediating variable in a relationship between companies' operating and financial performance and proactive environmental strategy $[14,27,29,32,65]$. Thus, based on previous literature, we have framed the subsequent hypotheses:

H9A. The eco-innovation positively and significantly mediates in an association of companies' operational performance and proactive environmental strategy.

H9B. The eco-innovation positively and significantly mediates in an association of companies' operational performance and planning and organizational practices.

H9C. The eco-innovation positively and significantly mediates in an association of companies' operational performance and operational practices.

H9D. The eco-innovation positively and significantly mediates in an association of companies' operational performance and communicational practices.

H10A. The eco-innovation positively and significantly mediates in an association of companies' financial performance and proactive environmental strategy.

H10B. The eco-innovation positively and significantly mediates in an association of companies' financial performance and planning and organizational practices.

H10C. The eco-innovation positively and significantly mediates in an association of companies' financial performance and operational practices.

H10D. The eco-innovation positively and significantly mediates in an association of companies' financial performance and communicational practices. 


\subsection{Technological Advances as a Moderator}

The explanation of technological advances is founded on the universal comprehension of scientific innovation outlined by the Oslo Manual [66] that differentiates processes and products or services innovations. According to Seid [16], Ioppolo et al. [67], and Ziegler and Nogareda [68], technological advances have a significant impact on services and products innovation, which is a specialized type of technological eco-innovation comprising of unique and highly upgraded services, processes, and products that reduce environmental hazards. The new technological advancement provides green capacities and specific resources with the help of scientific innovation. According to the natural resources-based approach, proactive environmental strategies offer the cumulative abilities and resources to secure environmental deprivation through environmentally friendly technologies, processes, and products $[15,42,56]$. Thus, technological advances help develop and experiment with novel openings at the corporate natural interface effectively and efficiently [55]. Technological advancement provides better eco-innovation strategies, which create the best-specialized strategies to prevent environmental hazards, reduce energy costs, and encourage sustainable development for an organization [2]. Several research studies have confirmed that technological advances indirectly impact the association of operational and financial performance, determinants of proactive environmental strategies [2]. According to Hsiao and Wang [36], Watson et al. [69], Liu et al. [70], Li et al. [71], and Salvadó et al. [72], technological advances have a vital role as a moderating variable in an association of operational and financial performance, determinants of proactive environmental strategies. Hence, we have framed the following hypotheses:

H11A. Technological advances significantly moderate in an association of operational performance and proactive environmental strategy.

H11B. Technological advances significantly moderate in an association of operational performance and planning and organizational practices.

H11C. Technological advances significantly moderate in an association of operational performance and operational practices.

H11D. Technological advances significantly moderate in an association of operational performance and communicational practices.

H12A. Technological advances significantly moderate in an association of financial performance and proactive environmental strategy.

H12B. Technological advances significantly moderate in an association of financial performance and planning and organizational practices.

H12C. Technological advances significantly moderate in an association of financial performance and operational practices.

H12D. Technological advances significantly moderate in an association of financial performance and communicational practices.

\subsection{Theoretical and Conceptual Framework}

We have derived a modified theoretical and conceptual framework from the previous literature. For instance, the modified items and constructs are derived from previous literature, such as planning and organizational practices and operational and communicational practices from previous studies $[5,12,17,18,20-25,37,53,59]$. The adapted items of the firm's operational and financial performance were taken from $[2,15,23,35,60,73]$. The modified items of eco-innovation were taken from [16,29,30,32,61-65]. The modified items of technological advances were taken from previous literature [33,56,66-69,71,72]. Figure 1 demonstrates the pictorial diagram of the modified theoretical and conceptual model of the study. 


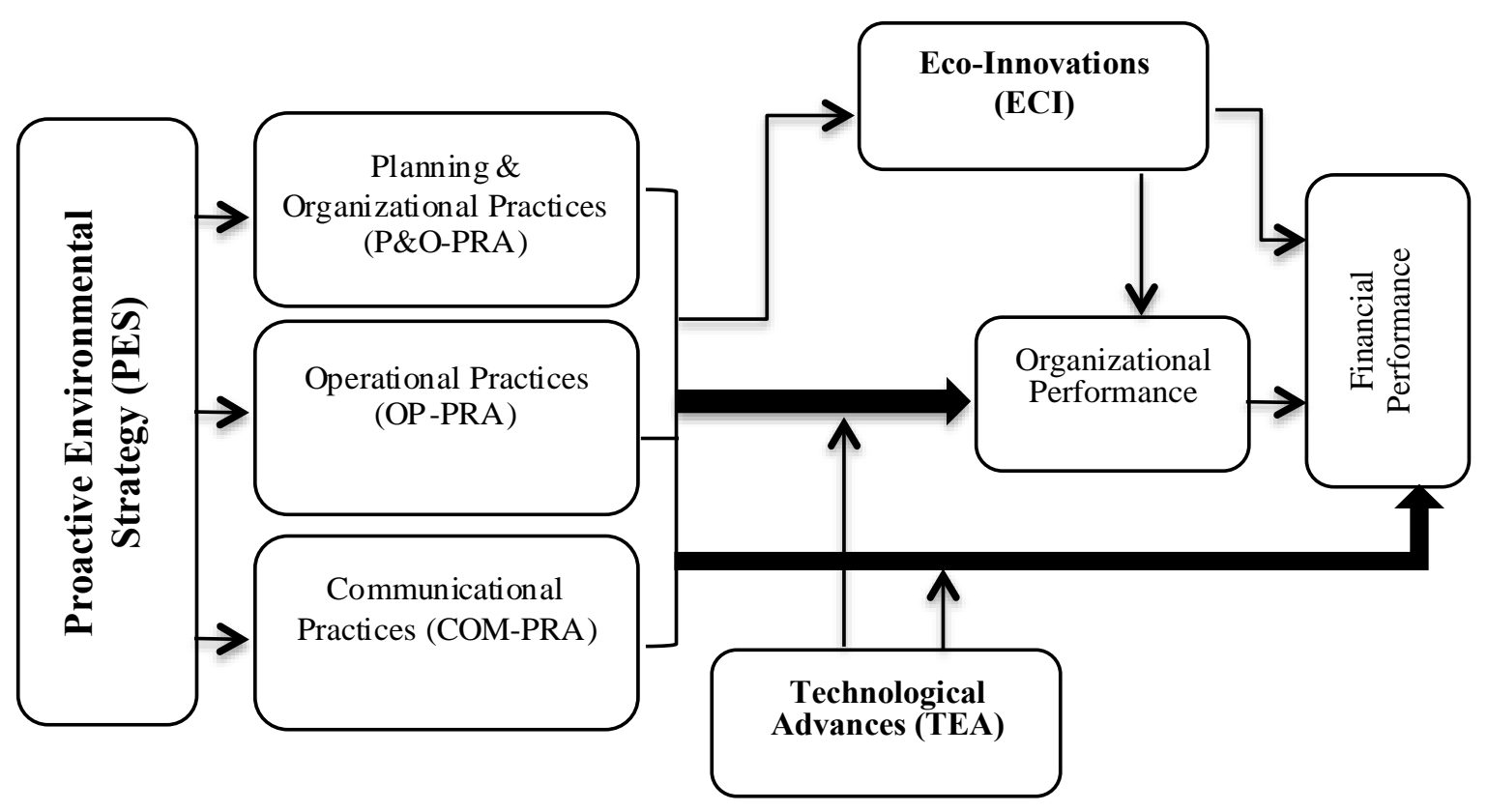

Figure 1. Theoretical and Conceptual Modified Model. Source: Previous literature $[5,12,17-25,37,53,59,69,71]$.

\section{Methodology}

\subsection{Measurement Scales and Research Design}

The study's nature is cross-sectional; we have used a quantitative and deductive method to conduct the research study. The measurement scales of the modified survey form were taken from earlier studies; we have employed adapted items of proactive environmental strategy and its determinants, for instance, planning and organizational practices and operational and communicational practices from previous studies such as $[5,12,17-25,37,53,59]$. The adapted items of the firm's operational and financial performance were taken from $[2,15,23,35,60,73]$. The modified measurement scales of eco-innovation were taken from $[16,29,30,32,61-65]$. The modified items of technological advances were taken from previous literature [33,56,66-72].

\subsection{Data Collection and Sampling Strategy}

We have used a non-probability sampling technique, for instance, purposive with quota sampling techniques; initially, we have screened our sampling frame according to the undertaken study's objectives. After selecting the sampling frame through a purposive sampling technique, we employed a quota-sampling method to represent each country's sample according to the pharmaceutical industry's size. The data was collected through personal emails, landline phones, and LinkedIn social media; we have collected 856 responses from different pharmaceutical companies, of which 253 companies belong to China, 231 companies to India, 201 to Pakistan, 128 to Bangladesh, and 43 to Sri Lanka. We approached 990 companies and their officials, but we received 886 responses in complete and comprehensive manners. Thus, the response rate was $86.46 \%$, which is considered an adequate number [74].

\subsection{Estimation Techniques for Data Analyses}

We have employed essential statistical techniques to estimate data analysis first, such as descriptive statistics to identify the vital characteristics of factors. Moreover, skewness, standard deviation, and kurtosis verified the normality of the data, which is a pre-requisite for SEM-based modeling. We further employed SEM-based multivariate techniques, such as exploratory factor analysis (EFA), to confirm and condense modified constructs and items. We used Kaiser-Meyers-Olkin (KMO), Bartlett's Sphericity methods, rotated component matrix analysis, and total variance explained methods in EFA. The 
EFA method is a vigorous technique to validate the incorporated items and constructs and sample adequacy and appropriateness.

Moreover, we used confirmatory factor analysis (CFA) to ascertain adopted constructs and items for our hypothesized model. We analyzed both hypothesized measurement and structural models through fit-indices values. Conclusively, we used the conditional process approach for indirect and direct (mediation and moderation) relationship and hypotheses checking. For the data analysis purposes, SPSS22, AMOS22, MS Excel, and conditional process modeling software were used.

\subsection{Demographic Profile of Respondents}

The data was collected through a modified and structured 5-point Likert scale and modified questionnaire. We have collected 856 responses from different pharmaceutical companies in China, India, Pakistan, Bangladesh, and Sri Lanka. Of 856 respondents, $456(56.21 \%)$ were male, and $400(44.12 \%)$ female; the rest of the demographic statistics are displayed in Table 1 . We have used ' $K$ ' for thousands (000), and income was converted into the United States dollar for homogeneity purposes. Additionally, Figure 2 demonstrated the graphical explanation of the demographic statistics of respondents (Please see in Supplementary Materials).

Table 1. Demographics of Respondents.

\begin{tabular}{|c|c|c|c|}
\hline \multicolumn{2}{|c|}{ Demographics } & \multirow{2}{*}{$\begin{array}{c}\text { Frequency } \\
468\end{array}$} & \multirow{2}{*}{$\begin{array}{c}\text { Percent } \\
54.7 \%\end{array}$} \\
\hline & Male & & \\
\hline Gender & Female & 388 & $45.3 \%$ \\
\hline \multirow{3}{*}{ Marital Status } & Single & 505 & $59.0 \%$ \\
\hline & Married & 323 & $37.3 \%$ \\
\hline & Divorced & 28 & $3.3 \%$ \\
\hline \multirow{5}{*}{ Age (In Years) } & $20-30$ & 297 & $34.7 \%$ \\
\hline & $30-40$ & 180 & $21.0 \%$ \\
\hline & $40-50$ & 112 & $13.1 \%$ \\
\hline & $50-60$ & 144 & $16.8 \%$ \\
\hline & More than 60 & 123 & $14.4 \%$ \\
\hline \multirow{4}{*}{ Education } & Graduation & 379 & $44.3 \%$ \\
\hline & Post-Graduation (Local) & 278 & $32.4 \%$ \\
\hline & Post-Graduation (Foreign) & 130 & $15.2 \%$ \\
\hline & Ph.D. degree & 69 & $8.1 \%$ \\
\hline \multirow{5}{*}{ Experience (In Years) } & $1-5$ & 225 & $26.3 \%$ \\
\hline & $5-10$ & 252 & $29.4 \%$ \\
\hline & $10-15$ & 107 & $12.5 \%$ \\
\hline & $15-20$ & 119 & $13.9 \%$ \\
\hline & More than 20 & 153 & $17.9 \%$ \\
\hline \multirow{5}{*}{ Income (In USD 000) } & $2-5$ & 151 & $17.6 \%$ \\
\hline & $6-9$ & 369 & $43.2 \%$ \\
\hline & $10-13$ & 175 & $20.4 \%$ \\
\hline & 14-17 & 103 & $12.0 \%$ \\
\hline & More than 18 & 58 & $6.8 \%$ \\
\hline \multicolumn{2}{|c|}{ Total-N } & \multicolumn{2}{|c|}{856} \\
\hline
\end{tabular}

Note: Post-graduation: Masters, Masters of Philosophy, or any other professional Master degree. 


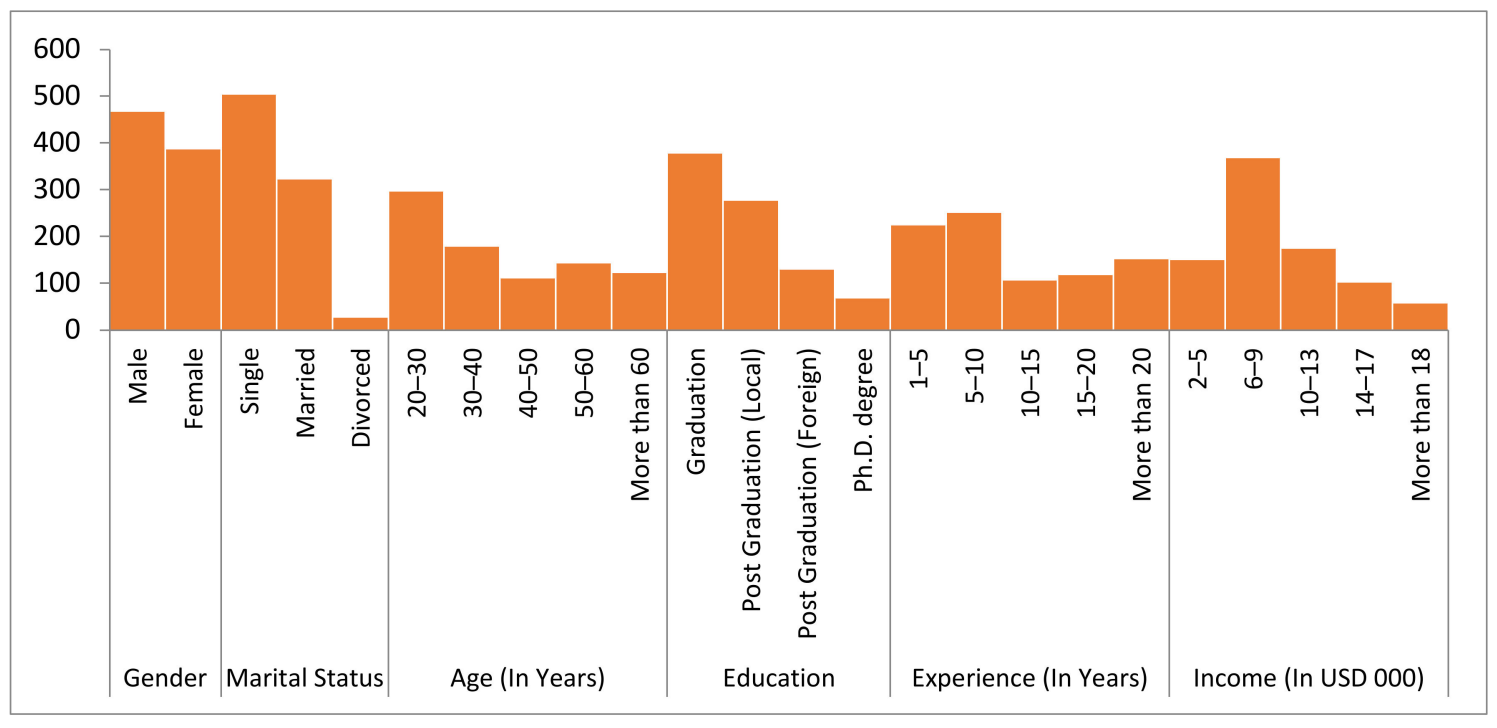

Figure 2. Demographic Statistics of Respondents. Source: Authors' calculation.

\section{Findings and Data Analyses}

\subsection{Common Method Bias}

The latent variables influence the reliabilities, covariations, and validities through common method bias (CMB). The CMB mechanism, procedural remedies, and causes are categorized and tackled through the procedure and design of the study. The CMB fixes problems in the ability to respond accurately, cognitive complexity, and scale ambiguity. It also addresses the control of similar scales and types of labels and reduces the bias of answers through differentiated, revised questions. Moreover, at the data analyses stage, we already examined the collinearity through a common biased method.

\subsection{Descriptive Analyses}

We used descriptive analyses to identify the essential characteristics, for instance, skewness, mean, kurtosis, and standard deviation. The normality of data is also measured through kurtosis, skewness, and standard deviation. For this purpose, we converted data into z-scores, measured skewness, standard deviation, and kurtosis. The findings of Table 2 confirmed that the measures of standard deviation and skewness range between \pm 1.5 , and kurtosis between \pm 3 . Thus, it is confirmed that our data is displaying a normality pattern [75]. As we used non-probability sampling techniques, data normality is a precondition for using the SEM-based multivariate approach and other parametric statistical methods [76]. Figure 3 demonstrates the graphical explanation of fundamental characteristics of descriptive analysis such as the mean, standard deviation, skewness, and kurtosis of collected data. Figure 3 also confirms the normality pattern of the data, and now we can move forward to PLS-SEM modeling. 
Table 2. Descriptive Analysis.

\begin{tabular}{cccccccc}
\hline \multirow{2}{*}{ Factors } & $\mathbf{N}$ & Mean & Std. Deviation & \multicolumn{2}{c}{ Skewness } & \multicolumn{2}{c}{ Kurtosis } \\
\cline { 2 - 7 } & Statistic & Statistic & Statistic & Statistic & Std. Error & Statistic & Std. Error \\
\hline Operational Performance & 856 & 3.7570 & 1.09409 & -0.845 & 0.084 & 0.142 & 0.167 \\
\hline Financial Performance & 856 & 3.7640 & 1.09988 & -0.797 & 0.084 & 0.070 & 0.167 \\
\hline $\begin{array}{c}\text { Proactive Environmental } \\
\text { Strategy }\end{array}$ & 856 & 3.8879 & 1.11933 & -0.896 & 0.084 & 0.180 & 0.167 \\
\hline $\begin{array}{c}\text { Planning and } \\
\text { Organizational Practices }\end{array}$ & 856 & 3.8575 & 1.00909 & -0.951 & 0.084 & 1.005 \\
\hline $\begin{array}{c}\text { Operational Practices } \\
\text { Communicational }\end{array}$ & 856 & 3.9019 & 1.12689 & -0.902 & 0.084 & 0.153 \\
\hline $\begin{array}{c}\text { Practices } \\
\text { Eco-innovation }\end{array}$ & 856 & 3.8107 & 1.07352 & -0.886 & 0.084 & 0.167 \\
\hline Technological Advances & 856 & 3.8107 & 1.07352 & -0.886 & 0.084 & 0.167 \\
\hline
\end{tabular}

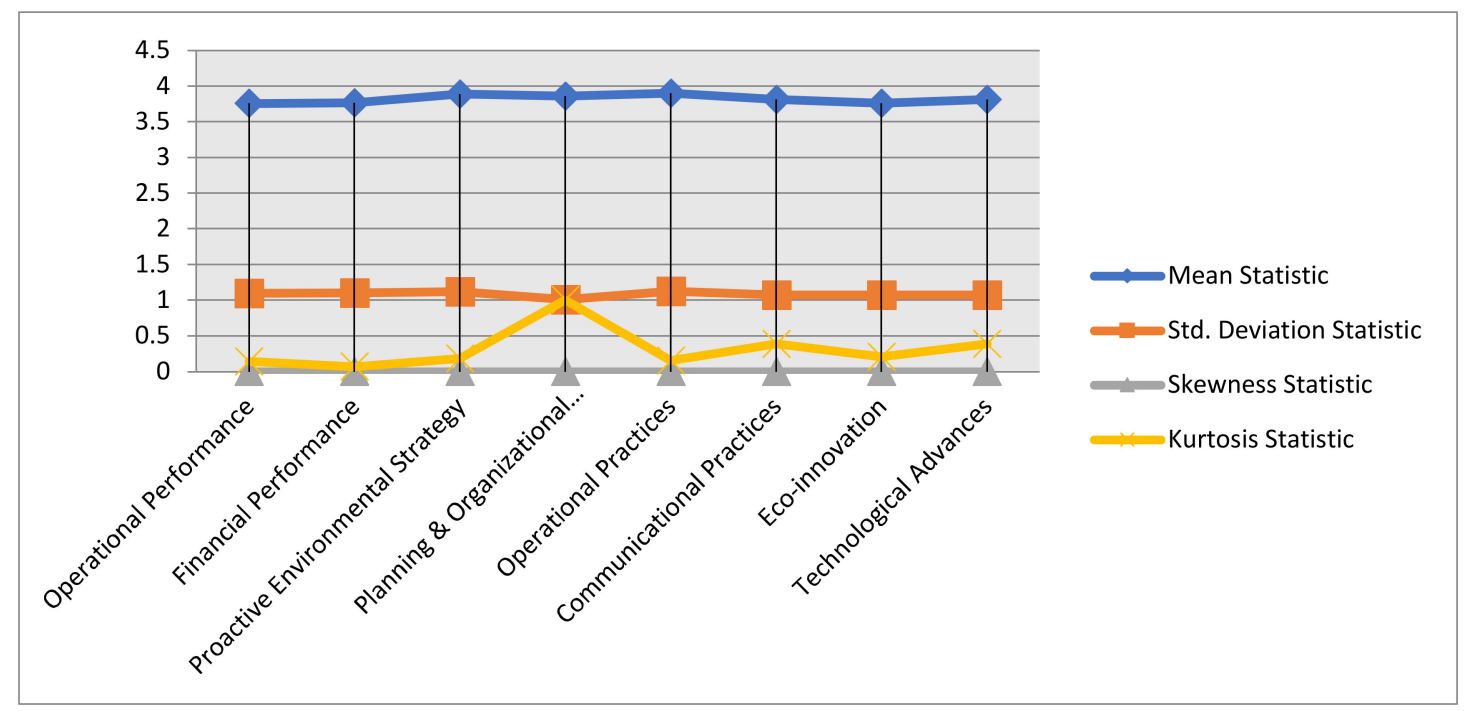

Figure 3. Descriptive Analysis. Source: Authors' calculation.

\subsection{Reliabilities and Validities}

We have extracted the rotated component matrix through principal component analysis to measure factor loadings, composite reliabilities, convergent validities, and discriminant validities. Table 3 exhibits that the factor loadings (FL) range from 0.85-0.95, which also met the requirement of the discriminant validity [77]. Additionally, Cronbach's alpha (CA) and composite reliabilities (CR) measurements are higher than 0.60; hence, we consider all the items and constructs to be valid [75]. Moreover, average variance extracted (AVE) readings are more significant than 0.50 for considered constructs, which satisfy the requirements of convergent validities [78]. Figure 4 verifies the graphical explanation of factor loadings of items, Cronbach's alphas, composite reliability, and average variance extracted of constructs that established the reliability and validity for assessing the measurement model. 
Table 3. Reliabilities and validities.

\begin{tabular}{|c|c|c|c|c|c|}
\hline Factors & Items & FL & CA & CR & AVE \\
\hline \multirow{3}{*}{ Operational Performance } & OP1 & 0.935 & \multirow{3}{*}{0.918} & \multirow{3}{*}{0.941} & \multirow{3}{*}{0.843} \\
\hline & OP2 & 0.885 & & & \\
\hline & OP3 & 0.935 & & & \\
\hline \multirow{3}{*}{ Financial Performance } & FP1 & 0.928 & \multirow{3}{*}{0.925} & \multirow{3}{*}{0.946} & \multirow{3}{*}{0.856} \\
\hline & FP2 & 0.895 & & & \\
\hline & FP3 & 0.952 & & & \\
\hline \multirow{3}{*}{ Proactive Environmental Strategy } & PES1 & 0.929 & \multirow{3}{*}{0.923} & \multirow{3}{*}{0.945} & \multirow{3}{*}{0.852} \\
\hline & PES2 & 0.891 & & & \\
\hline & PES3 & 0.949 & & & \\
\hline \multirow{3}{*}{ Planning and Organizational Practices } & POP1 & 0.928 & \multirow{3}{*}{0.928} & \multirow{3}{*}{0.949} & \multirow{3}{*}{0.862} \\
\hline & POP2 & 0.905 & & & \\
\hline & POP3 & 0.952 & & & \\
\hline \multirow{3}{*}{ Operational Practices } & OPR1 & 0.923 & \multirow{3}{*}{0.897} & \multirow{3}{*}{0.925} & \multirow{3}{*}{0.805} \\
\hline & OPR2 & 0.897 & & & \\
\hline & OPR3 & 0.872 & & & \\
\hline \multirow{3}{*}{ Communicational Practices } & CP1 & 0.929 & \multirow{3}{*}{0.926} & \multirow{3}{*}{0.947} & \multirow{3}{*}{0.857} \\
\hline & $\mathrm{CP} 2$ & 0.899 & & & \\
\hline & $\mathrm{CP} 3$ & 0.949 & & & \\
\hline \multirow{3}{*}{ Eco-innovation } & EIN1 & 0.916 & \multirow{3}{*}{0.887} & \multirow{3}{*}{0.917} & \multirow{3}{*}{0.787} \\
\hline & EIN2 & 0.887 & & & \\
\hline & EIN3 & 0.859 & & & \\
\hline \multirow{3}{*}{ Technological Advances } & TEA1 & 0.933 & \multirow{3}{*}{0.923} & \multirow{3}{*}{0.945} & \multirow{3}{*}{0.851} \\
\hline & TEA2 & 0.914 & & & \\
\hline & TEA3 & 0.921 & & & \\
\hline
\end{tabular}

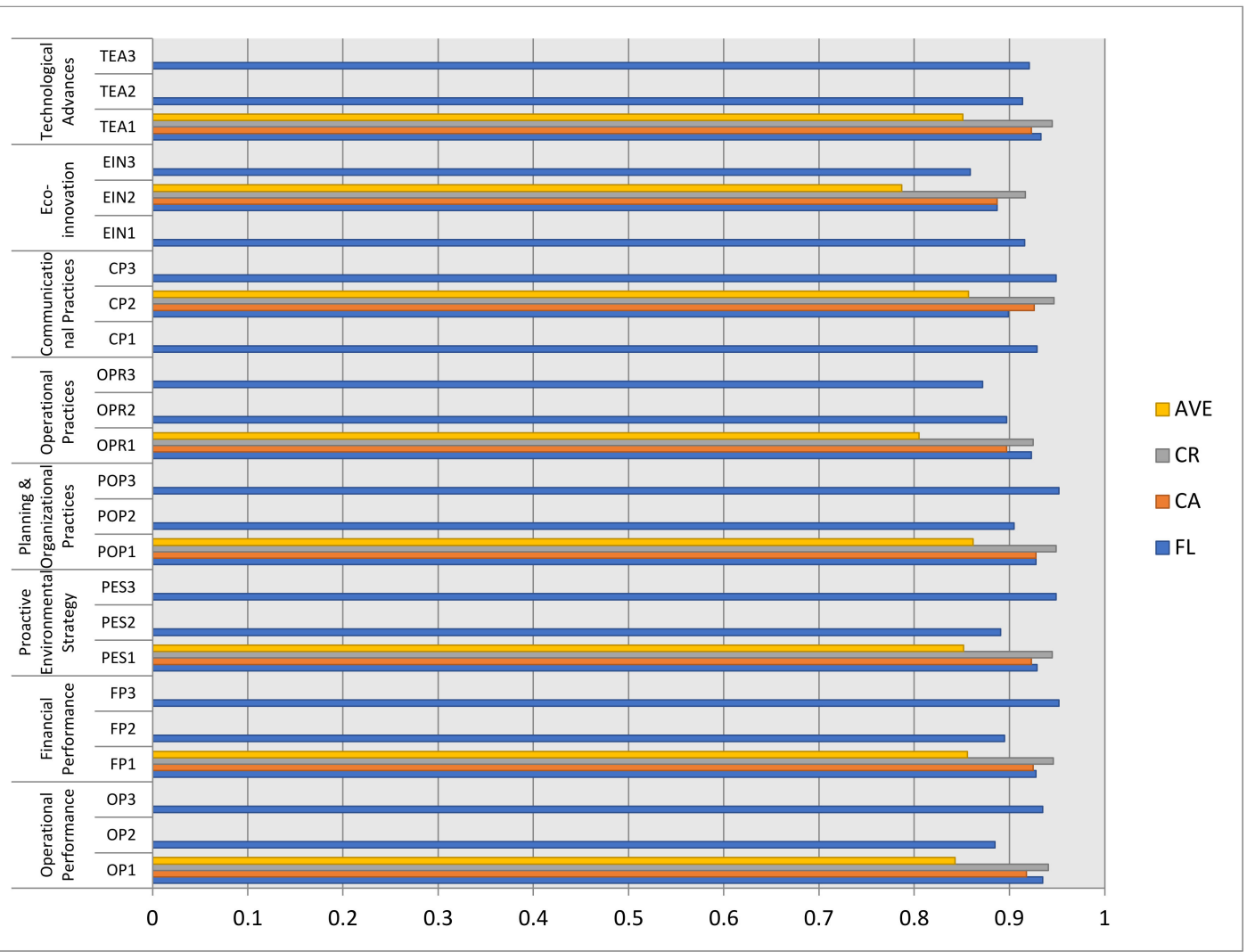

Figure 4. Reliabilities and Validities. Source: Authors' calculation. 


\subsection{Exploratory Factor Analysis-EFA}

We have employed a modified theoretical and conceptual model in which we used adapted constructs and items; thus, we checked these items' authenticity and construct for our hypothesized model in EFA. The EFA also reduces and condenses the unnecessary items and constructs. In our hypothesized model, we used eight constructs and twentyfour items. We incorporated four independent variables such as proactive environmental strategy and its three determinants, i.e., planning and organizational practices, operational practices, and communicational practices, with three items each. Moreover, we employed one mediating variable, i.e., eco-innovation, with three items, one moderating variable, i.e., technological advances, three items, and two dependent variables: operational performance and financial performance, three items each. The findings of Table 3 suggested that we should retain all the constructs and items as each item has more than 0.60 factor loading $0.60[74,79]$.

\subsection{Kaiser-Meyers-Olkin, Bartlett's, and Total Variance Explained Analyses}

In EFA, we used Kaiser-Meyers-Olkin (KMO) analysis for checking the data robustness and suitability; the findings of Table 4 demonstrate that the measurement of KMO is 0.746 , which shows a reasonably good value vis à vis the threshold value of 0.50 [80]. The appropriateness of data is checked through Bartlett's Sphericity analysis which shows $p<0.05$. Thus, our collected information is pertinent to the SEM-based multivariate approach, and we can proceed further. Finally, in EFA, we employed the total variance explained analysis that shows the percentage total cumulative variance of $86.50 \%$, which is considered acceptable against the minimum threshold value of 0.50 . The eigenvalues of each construct are more than one. Thus, both eigenvalues and cumulative variance confirmed the suitability of constructs and our collected data. Figures 5 and 6 confirm the appropriateness and adequacy of data using total variance explained, Kaiser-Meyers-Olkin (KMO) analysis, and Bartlett's analysis.

Table 4. Total variance explained.

\begin{tabular}{|c|c|c|c|c|c|c|c|c|c|}
\hline \multirow[t]{2}{*}{ Component } & \multicolumn{3}{|c|}{ Initial Eigenvalues } & \multicolumn{3}{|c|}{$\begin{array}{l}\text { Extraction Sums of Squared } \\
\text { Loadings }\end{array}$} & \multicolumn{3}{|c|}{$\begin{array}{c}\text { Rotation Sums of Squared } \\
\text { Loadings }\end{array}$} \\
\hline & Total & $\begin{array}{c}\% \text { of } \\
\text { Variance }\end{array}$ & $\begin{array}{c}\text { Cumulative } \\
\%\end{array}$ & Total & $\begin{array}{c}\% \text { of } \\
\text { Variance }\end{array}$ & $\begin{array}{l}\text { Cumulative } \\
\%\end{array}$ & Total & $\begin{array}{c}\% \text { of } \\
\text { Variance }\end{array}$ & $\underset{\%}{\text { Cumulative }}$ \\
\hline 1 & 3.195 & 13.313 & 13.313 & 3.195 & 13.313 & 13.313 & 2.621 & 10.922 & 10.922 \\
\hline 2 & 3.048 & 12.699 & 26.013 & 3.048 & 12.699 & 26.013 & 2.612 & 10.884 & 21.806 \\
\hline 3 & 2.727 & 11.362 & 37.375 & 2.727 & 11.362 & 37.375 & 2.600 & 10.832 & 32.638 \\
\hline 4 & 2.574 & 10.724 & 48.098 & 2.574 & 10.724 & 48.098 & 2.586 & 10.774 & 43.413 \\
\hline 5 & 2.526 & 10.525 & 58.623 & 2.526 & 10.525 & 58.623 & 2.571 & 10.711 & 54.124 \\
\hline 6 & 2.245 & 9.355 & 67.978 & 2.245 & 9.355 & 67.978 & 2.559 & 10.664 & 64.788 \\
\hline 7 & 2.234 & 9.310 & 77.288 & 2.234 & 9.310 & 77.288 & 2.465 & 10.269 & 75.057 \\
\hline 8 & 1.861 & 7.752 & 85.041 & 1.861 & 7.752 & 85.041 & 2.396 & 9.984 & 85.041 \\
\hline \multicolumn{10}{|c|}{ Bartlett's and KMO Results } \\
\hline \multicolumn{7}{|c|}{ Kaiser-Meyer-Olkin Measure of Sampling Adequacy. } & \multicolumn{3}{|c|}{0.705} \\
\hline \multirow{3}{*}{\multicolumn{4}{|c|}{ Bartlett's Test of Sphericity }} & \multicolumn{3}{|c|}{ Approx. Chi-Square } & \multicolumn{3}{|c|}{$15,406.272$} \\
\hline & & & & \multicolumn{3}{|c|}{ Df } & \multicolumn{3}{|c|}{276} \\
\hline & & & & \multicolumn{3}{|c|}{ Sig. } & \multicolumn{3}{|c|}{0.000} \\
\hline
\end{tabular}

Note: Df: Degree of freedom; Sig.: Significance value = Probability value. 


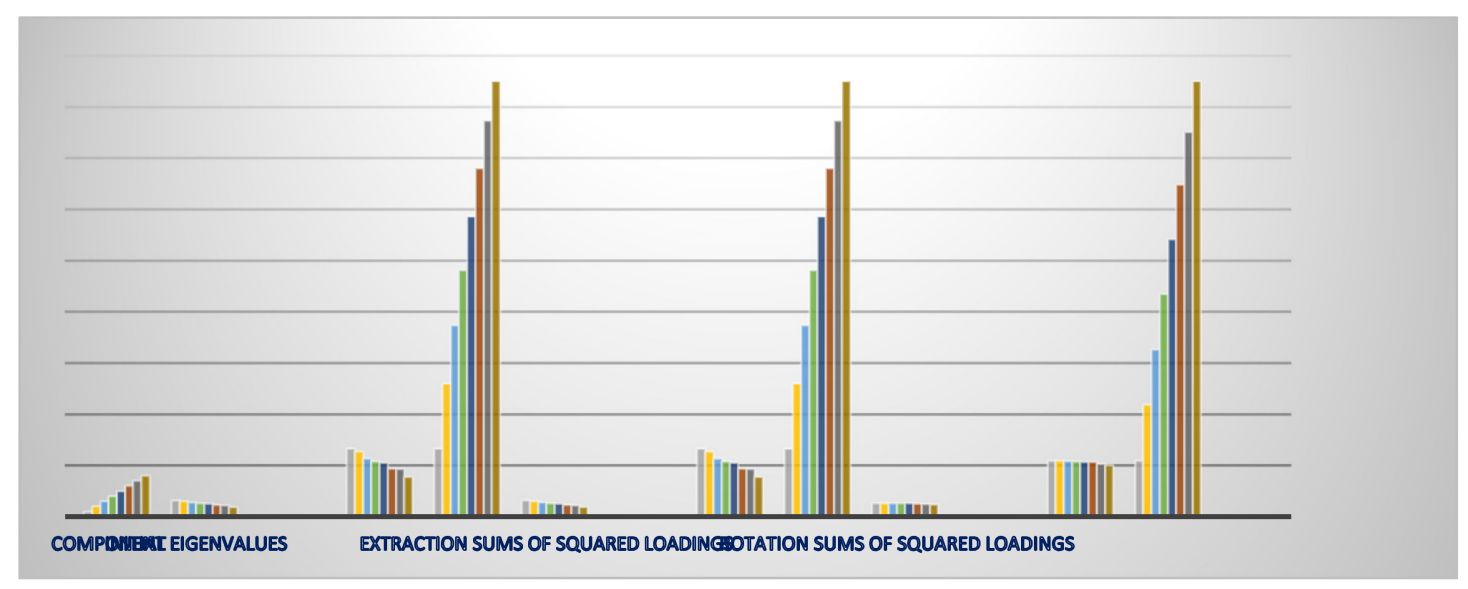

Figure 5. Total Variance Explained Analysis. Source: Authors' calculation.

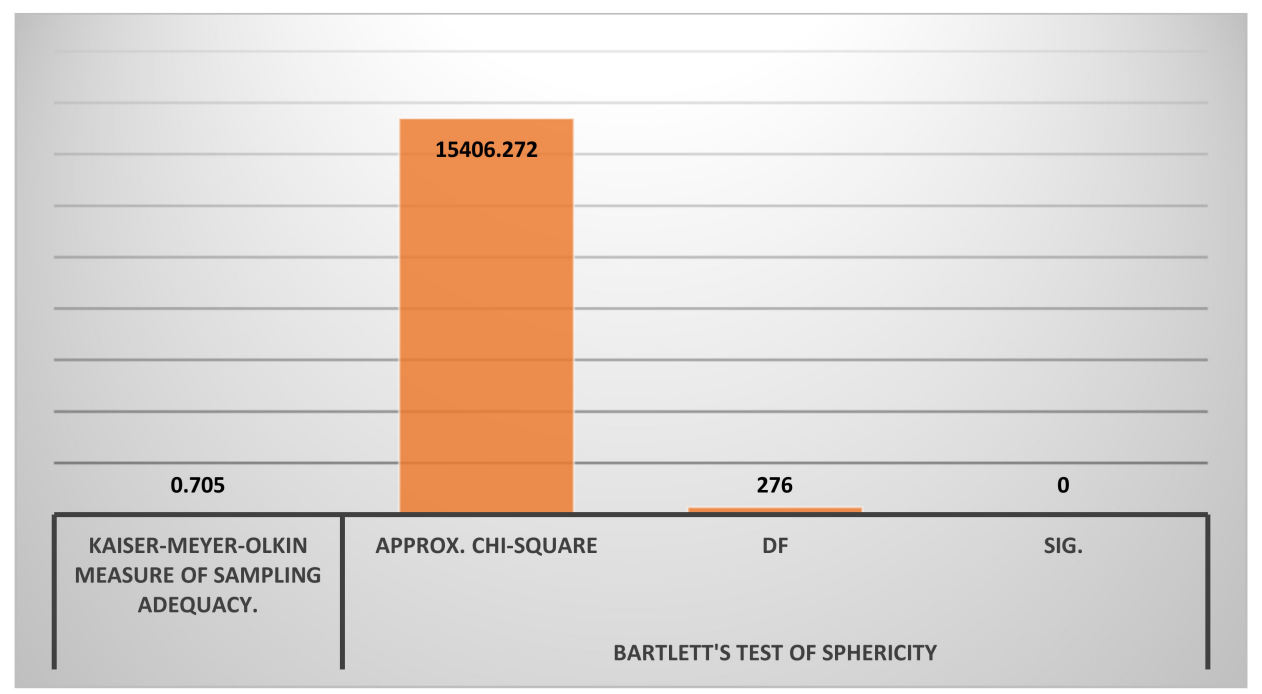

Figure 6. Kaiser-Meyers-Olkin, Bartlett's Analysis. Source: Authors' calculation.

\subsection{Confirmatory Factor Analysis-CFA}

The CFA is a proper and undeviating method for checking the hypothesized measurement model; we incorporated eight constructs and twenty-four items in our measurement model. We assimilated four independent variables, such as proactive environmental strategy and its three determinants, i.e., planning and organizational practices, operational practices, and communicational practices, with three items each. Moreover, we employed one mediating variable, i.e., eco-innovation with three items, one moderating variable, i.e., technological advances with three items. Furthermore, we used two dependent variables, such as operational performance and financial performance, with three items each, and inculcated our data into observed and non-observed variables in the CFA method [77]. The findings of Table 5 suggested that our hypothesized measurement model is valid for operational performance and financial performance, as the readings of every fit-indices followed the threshold limits [79]. Figure 7 confirmed the appropriateness of hypothesized measurement model for our considered modified model using fit indices values as provided in Table 5. 
Table 5. Fit-indices measures.

\begin{tabular}{|c|c|c|c|c|c|c|c|c|c|c|c|}
\hline \multirow{2}{*}{$\begin{array}{l}\text { The Goodness of Fit } \\
\text { Measures }\end{array}$} & \multicolumn{3}{|c|}{ Absolute Fit Indices } & \multicolumn{3}{|c|}{ Relative Fit Indices } & \multicolumn{3}{|c|}{$\begin{array}{l}\text { Non-Centrality-Based } \\
\text { Indices }\end{array}$} & \multicolumn{2}{|c|}{$\begin{array}{l}\text { Parsimonious Fit } \\
\text { Indices }\end{array}$} \\
\hline & $\chi^{2} / \mathrm{df}$ & Probability & GFI & NFI & IFI & TLI & CFI & RMSEA & RNI & PCFI & PNFI \\
\hline Measurement Model & 3.55 & 0.0312 & 0.97 & 0.93 & 0.99 & 0.97 & 0.98 & 0.025 & 0.99 & 0.82 & 0.80 \\
\hline Structural Model & 3.37 & 0.0301 & 0.98 & 0.92 & 0.98 & 0.96 & 0.97 & 0.028 & 0.96 & 0.81 & 0.79 \\
\hline Criterion (Threshold values) & $<5.0$ & $<0.05$ & $>0.95$ & $>0.90$ & $>0.95$ & $>0.95$ & $>0.95$ & $<0.05$ & $>0.95$ & $>0.75$ & $>0.75$ \\
\hline
\end{tabular}

PCFI: Parsimnious fit-index; PNFI: Parsimony-adjusted normed fit-index; $\chi^{2} / d$ : Relative chi-square; TLI: Tucker-Lewis index; NFI: Normed fixed-index; CFI: Comparative fit-index; GFI: Godness of fit-index; IFI: Incremental fixed-index; RMSEA: Root mean squared error of approximation; and RNI: Relative Non-centrality index. Note: $\chi^{2} / d$ : ratio of Chi-square value and degree of freedom; Fit-indices calculated through AMOS 22 in CFA, and probability is also an essential absolute fit index.

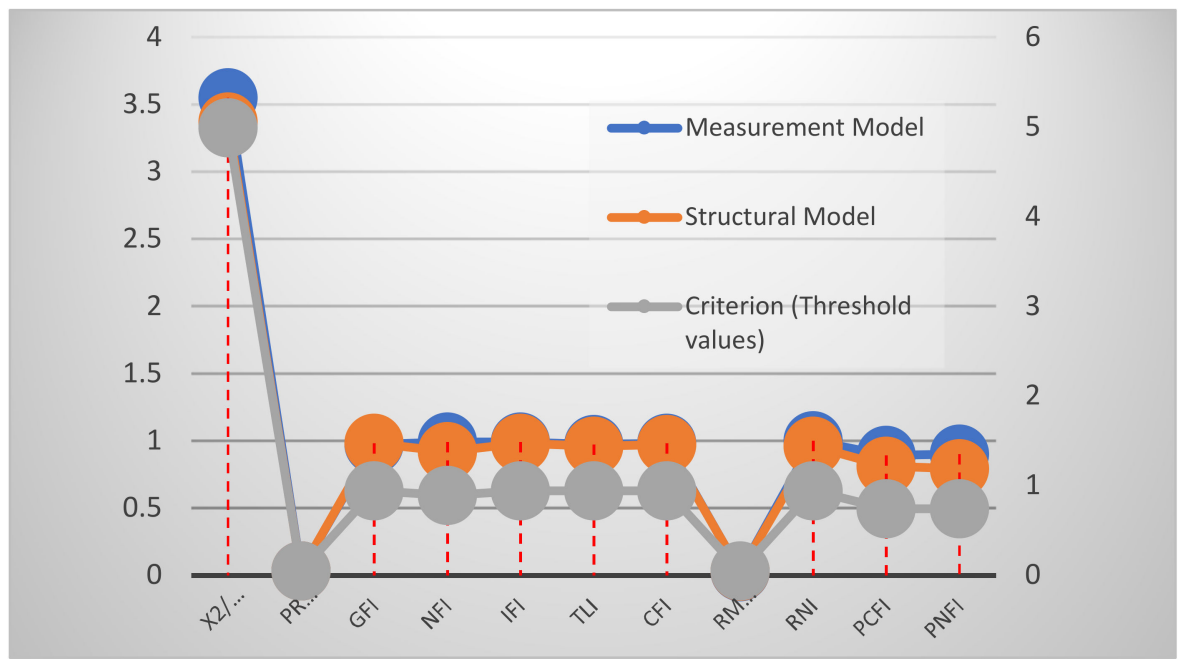

Figure 7. Fit-indices Measurements. Source: Authors' calculation.

\subsection{Structural Equation Modeling-SEM}

We also considered the hypothesized structural model with eight constructs and twenty-four items in the SEM-based multivariate approach. With three items, we assimilated four independent variables, such as proactive environmental strategy and its three determinants, i.e., planning and organizational practices, operational practices, and communicational practices. Moreover, we employed one mediating variable, i.e., eco-innovation, with three items and one moderating variable, i.e., technological advances. We used two dependent variables, operational performance and financial performance, with three items. The findings of Table 5 suggested that our hypothesized structural model was acceptable for operational and financial performance, as the readings of every fit-indices followed the threshold limits [77,79]. Figure 7 confirmed the appropriateness of hypothesized structural model for our considered modified model using fit indices values as provided in Table 5.

\subsection{Postulated Direct Association}

The findings of Table 6 exhibit the standardized regression weights that show the impact of each independent variable, such as proactive environmental strategy and its three determinants, i.e., operating practices, communicational practices, and planning and organizational practices on the dependent variable, i.e., financial and operational performance. The study also evaluated the direct influence of operating performance on financial performance; we employed the conditional process technique for this purpose. The findings of Table 6 demonstrated that proactive environmental strategy and its three determinants, i.e., planning and organizational practices, operational practices, and communicational practices, have an affirmative and compelling impact on operational and financial performance. Moreover, the outcomes demonstrated that operating performance has an affirmative and significant impact on financial performance as $\mathrm{T}>2$ and 
$p<0.05$ in all cases. Thus, it is concluded that our postulates $\mathrm{H} 1$ to $\mathrm{H} 9$ are reinforced. The personal impact of independent variables demonstrated that proactive environmental strategy has the highest impact of 0.702 on operational performance, followed by the impact of communicational and operating practices with 0.601 and 0.566 on operational performance, respectively. Figure 8 confirms the direct association of independent and dependent variables of our considered modified model.

Table 6. Postulated direct association.

\begin{tabular}{|c|c|c|c|c|c|c|c|}
\hline Hypotheses & $\begin{array}{l}\text { Independent } \\
\text { Variables }\end{array}$ & $\begin{array}{l}\text { Regression } \\
\text { Paths }\end{array}$ & $\begin{array}{c}\text { Standardized } \\
\text { Regression Weights } \\
(\beta)\end{array}$ & SE & $\mathrm{T}$ & $P$ & Decision \\
\hline $\mathrm{H} 1 \mathrm{~A}$ & $\begin{array}{c}\text { Proactive } \\
\text { Environmental } \\
\text { Strategy } \\
\end{array}$ & $\mathrm{PES}+\rightarrow \mathrm{OP}$ & 0.7020 & 0.0199 & 35.19 & 0.0000 & Supported \\
\hline H1B & $\begin{array}{l}\text { Planning and } \\
\text { Organizational } \\
\text { Practices }\end{array}$ & $\mathrm{POP}+\rightarrow \mathrm{OP}$ & 0.4935 & 0.0468 & 13.41 & 0.0000 & Supported \\
\hline $\mathrm{H} 2$ & Operational Practices & $\mathrm{OPR}+\rightarrow \mathrm{OP}$ & 0.5662 & 0.0345 & 16.41 & 0.0000 & Supported \\
\hline $\mathrm{H} 3$ & $\begin{array}{c}\text { Communicational } \\
\text { Practices }\end{array}$ & $\mathrm{CP}+\rightarrow \mathrm{OP}$ & 0.6018 & 0.0322 & 18.71 & 0.0000 & Supported \\
\hline $\mathrm{H} 4$ & $\begin{array}{c}\text { Proactive } \\
\text { Environmental } \\
\text { Strategy }\end{array}$ & $\mathrm{PES}+\rightarrow \mathrm{FP}$ & 0.1864 & 0.0238 & 7.84 & 0.0000 & Supported \\
\hline H5 & $\begin{array}{l}\text { Planning and } \\
\text { Organizational } \\
\text { Practices }\end{array}$ & $\mathrm{POP}+\rightarrow \mathrm{FP}$ & 0.5388 & 0.0260 & 20.70 & 0.0000 & Supported \\
\hline H6 & Operational Practices & $\mathrm{OPR}+\rightarrow \mathrm{FP}$ & 0.3900 & 0.0282 & 13.84 & 0.0000 & Supported \\
\hline $\mathrm{H} 7$ & $\begin{array}{l}\text { Communicational } \\
\text { Practices }\end{array}$ & $\mathrm{CP}+\rightarrow \mathrm{FP}$ & 0.4801 & 0.0252 & 19.04 & 0.0000 & Supported \\
\hline $\mathrm{H} 8$ & $\begin{array}{l}\text { Operational } \\
\text { Performance }\end{array}$ & $\mathrm{OP}+\rightarrow \mathrm{FP}$ & 0.4223 & 0.0459 & 9.19 & 0.0000 & Supported \\
\hline
\end{tabular}

Note: $\uparrow=$ Predictor; $\mathrm{OP}=$ Operational performance; FP = Financial performance; $\mathrm{PES}=$ Proactive environmental strategy; $\mathrm{POP}=\mathrm{Planning}$ and organizational practices; $\mathrm{OPR}=$ Operational practices; and $\mathrm{CP}=$ Communicational practices.

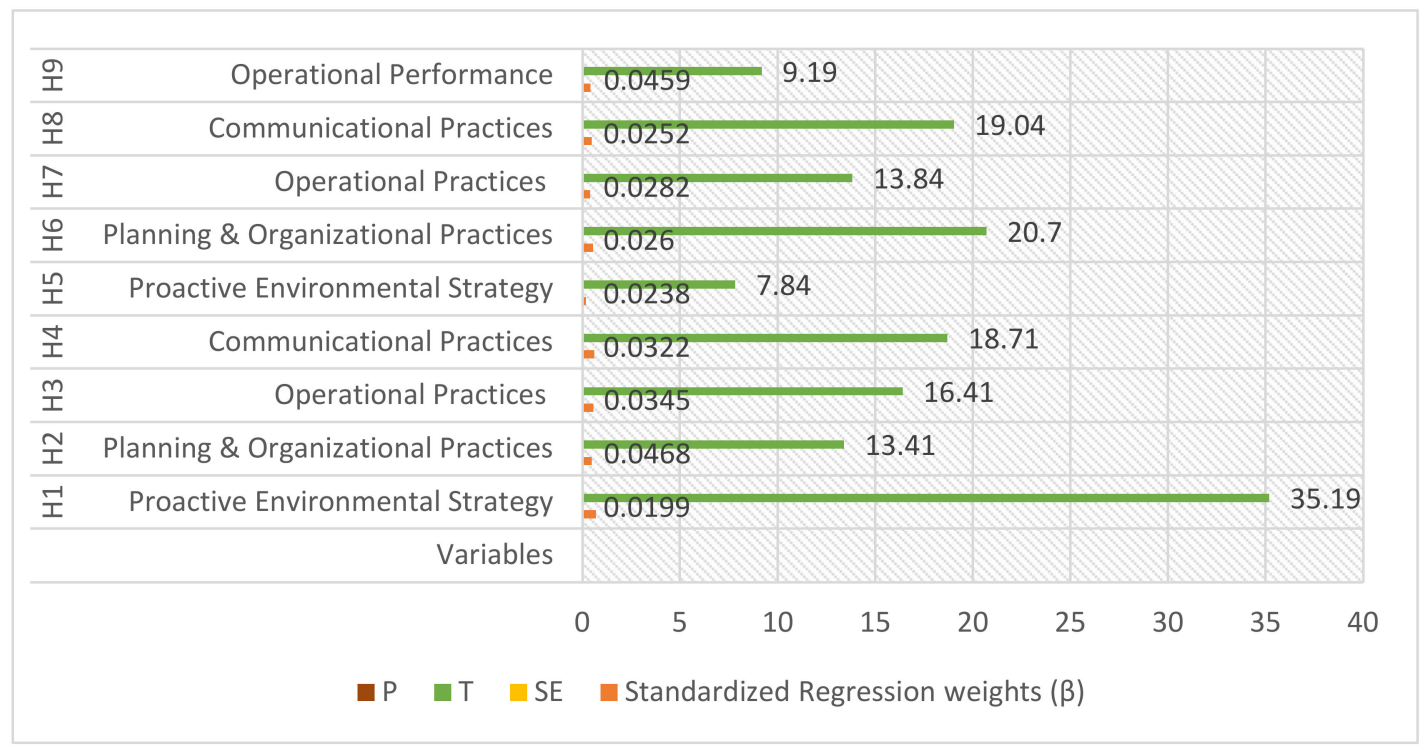

Figure 8. Postulated direct relationship. Source: Authors' calculation. 


\subsection{Mediation Analyses}

In our hypothesized modified model, we have incorporated eco-innovation as a mediating factor; the findings of Table 7 demonstrate that eco-innovation has an affirmative and cogent mediation in a relationship between exogenous variables and endogenous variables. We evaluated mediation using bootstrapping and normal theory method; in the bootstrapping process, we checked the zero between BootLLCI and BootULCI [81]. The findings of Table 7 exhibit that zero does not occur between BootLLCI and BootULCI. Therefore, it is concluded that the eco-innovation has an affirmative and cogent mediation between exogenous variables such as proactive environmental strategy and its three determinants, i.e., planning and organizational practices, operational practices, and communicational practices and endogenous variables, i.e., operational performance and financial performance. Thus, it is finally concluded that postulates H10A to H10D and H11A to H11D are supported. Similar results are inferred from the normal theory method, as in all the cases $Z> \pm 1.96$ and $p<0.05$ [82]. Thus, lastly, it is confirmed from the normal theory method that eco-innovation has an affirmative and cogent mediation between exogenous variables such as proactive environmental strategy and its three determinants, i.e., planning and organizational practices, operational practices, and communicational practices, and endogenous variables, i.e., operational performance and financial performance. Figures 9 and 10 confirm the indirect association of meditating variables in a relationship between independent and dependent variables of our considered modified model. Figure 9 demonstrates the bootstrapping method, and Figure 10 exhibits the outcomes of normal theory methods; both methods substantiated the mediation.

Table 7. Mediation analysis.

\begin{tabular}{|c|c|c|c|c|c|c|c|c|c|c|}
\hline \multirow[b]{2}{*}{ Hypotheses } & \multirow[b]{2}{*}{ Mediation } & \multicolumn{4}{|c|}{ Bootstrapping Method } & \multicolumn{4}{|c|}{ Normal Theory Method } & \multirow[b]{2}{*}{ Decisions } \\
\hline & & $\begin{array}{c}\text { Indirect } \\
\text { Effect }\end{array}$ & Boot SE & $\begin{array}{l}\text { Boot } \\
\text { LLCI }\end{array}$ & $\begin{array}{c}\text { Boot } \\
\text { ULCI }\end{array}$ & $\begin{array}{c}\text { Indirect } \\
\text { Effect }\end{array}$ & S.E. & $Z^{*}$ & Prob. ** & \\
\hline H9A: & $\mathrm{PES} \rightarrow \mathrm{EIN} \rightarrow \mathrm{OP}$ & 0.1845 & 0.0148 & 0.1556 & 0.2135 & 0.1845 & 0.0161 & 11.47 & 0.0000 & Supported \\
\hline H9B: & $\mathrm{POP} \rightarrow \mathrm{EIN} \rightarrow \mathrm{OP}$ & 0.3741 & 0.0250 & 0.3262 & 0.4241 & 0.3741 & 0.0317 & 11.78 & 0.0000 & Supported \\
\hline H9C: & $\mathrm{OPR} \rightarrow \mathrm{EIN} \rightarrow \mathrm{OP}$ & 0.2439 & 0.0207 & 0.2050 & 0.2861 & 0.2439 & 0.0301 & 8.11 & 0.0000 & Supported \\
\hline H9D: & $\mathrm{CP} \rightarrow \mathrm{EIN} \rightarrow \mathrm{OP}$ & 0.2565 & 0.0219 & 0.2163 & 0.3024 & 0.2565 & 0.0274 & 9.36 & 0.0000 & Supported \\
\hline H10A: & $\mathrm{PES} \rightarrow \mathrm{EIN} \rightarrow \mathrm{FP}$ & 0.5477 & 0.0235 & 0.5030 & 0.5947 & 0.5477 & 0.0242 & 22.64 & 0.0000 & Supported \\
\hline H10B: & $\mathrm{POP} \rightarrow \mathrm{EIN} \rightarrow \mathrm{FP}$ & 0.4240 & 0.0277 & 0.3718 & 0.4813 & 0.4240 & 0.0237 & 17.88 & 0.0000 & Supported \\
\hline H10C: & $\mathrm{OPR} \rightarrow \mathrm{EIN} \rightarrow \mathrm{FP}$ & 0.4492 & 0.0256 & 0.4028 & 0.5022 & 0.4492 & 0.0259 & 17.35 & 0.0000 & Supported \\
\hline H10D: & $\mathrm{CP} \rightarrow \mathrm{EIN} \rightarrow \mathrm{FP}$ & 0.4168 & 0.0254 & 0.3667 & 0.4673 & 0.4168 & 0.0230 & 18.10 & 0.0000 & Supported \\
\hline
\end{tabular}

Note: $\mathrm{OP}=$ Operational performance; FP = Financial performance; PES = Proactive environmental strategy; POP = Planning and organizational practices; $\mathrm{OPR}=$ Operational practices; $\mathrm{CP}=$ Communicational practices; $\mathrm{EIN}=$ Eco-innovation; ${ }^{*}$ Refers to $\mathrm{Z}> \pm 1.96$; and ** Indicates $p<0.05$.

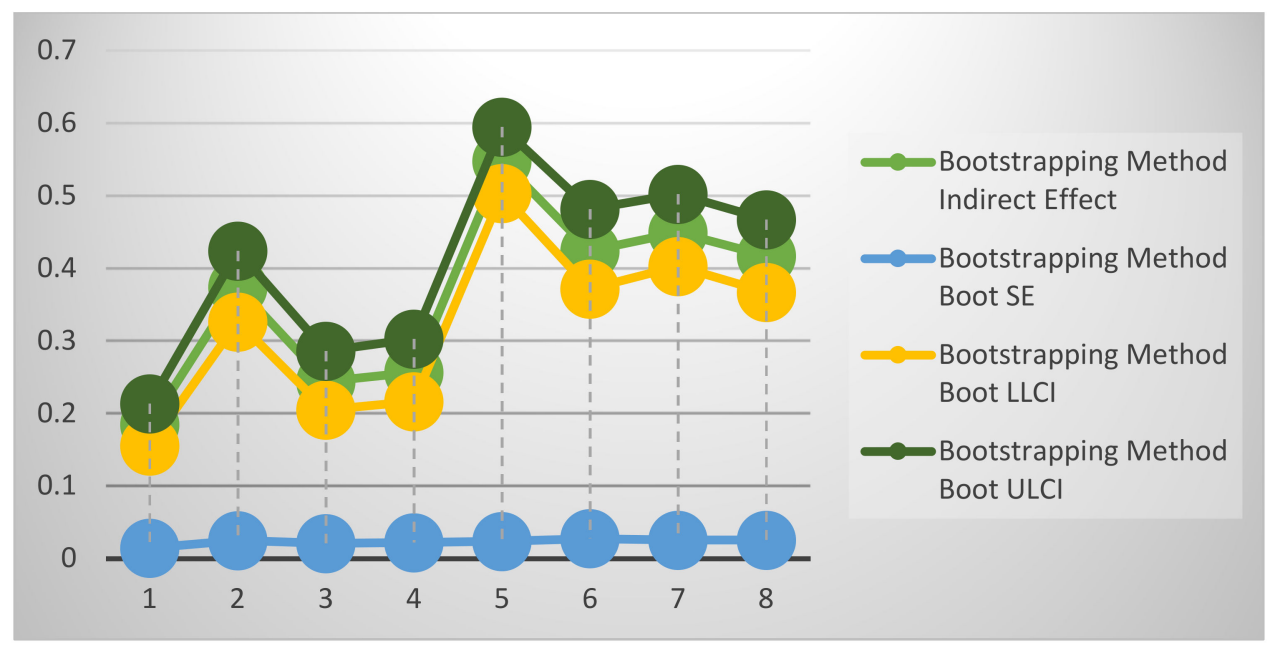

Figure 9. Mediation-Bootstrapping Method. Source: Authors' calculation. 


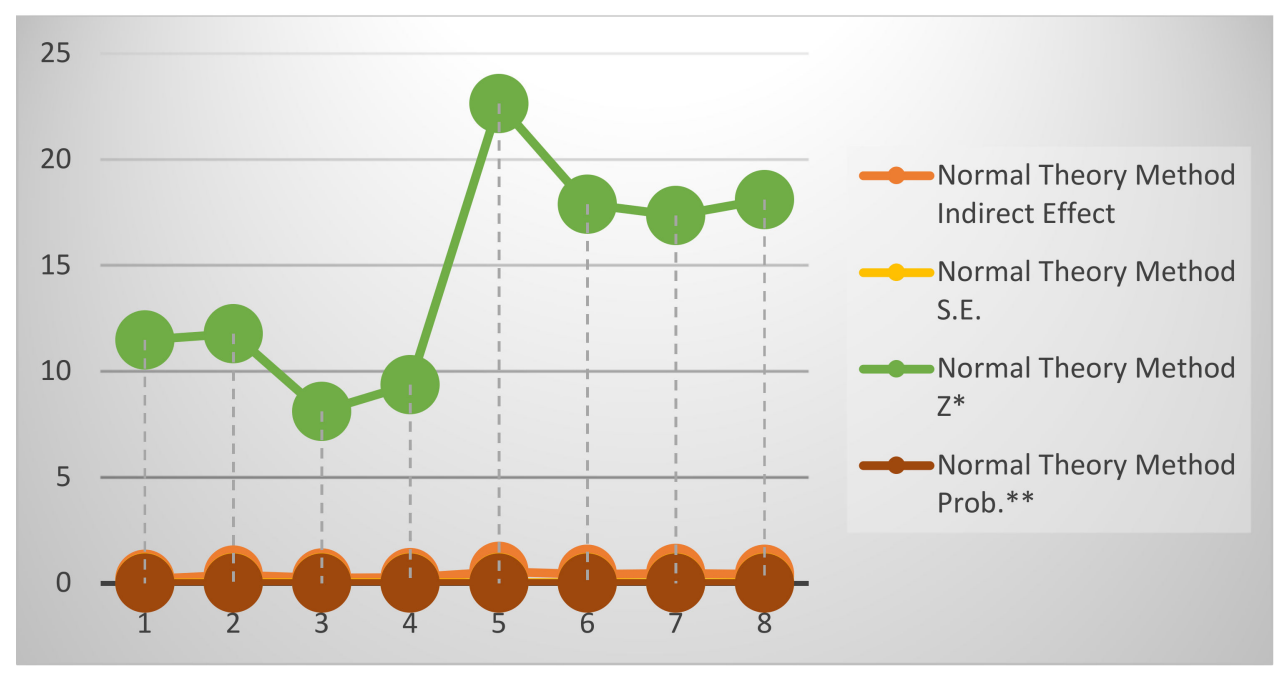

Figure 10. Mediation-Normal Theory Method. Source: Authors' calculation.

\subsection{Moderation Analyses}

In our hypothesized modified model, we have also incorporated technological advances as a moderating variable; the findings of Table 8 demonstrated that technological advances have a significant impact on moderation between exogenous variables and endogenous variables. We evaluated moderation by using Hayes's conditional process modeling [81]. The findings of Table 8 exhibited that $\mathrm{T}> \pm 2$ and $p<0.05$ and H12A, H12B, H12C, and H12D, and H13A, H13B, H13C, and H13D are reinforced. Subsequently, it is confirmed that the technological advances have an affirmative and significant mediation between exogenous variables such as proactive environmental strategy and its three determinants, i.e., planning and organizational practices, operational practices, and communicational practices, and endogenous variables, i.e., operational performance and financial performance.

\subsection{Conditional Graphical Display of Moderation}

We have identified that technological advances have a significant impact as a moderator between exogenous and endogenous variables; however, moderation's graphical display is vital to conclude the final result [81]. Thus, we have evaluated the moderation through conditional visual presentation, as demonstrated in Figures 11-18. The findings of Figures 11-18 exhibit that with the change of every measurement of moderating variable, there is a change in outcome variables, which confirms that the shift in moderating variable brought a change in endogenous variables. The blue lines show exogenous variables such as proactive environmental strategy and its three determinants, i.e., planning and organizational practices, operating practices, and communicational practices. However, the orange lines demonstrate the moderating variable (technological advances), and gray lines represent the endogenous variables (operational performance and financial performance). Hence, it is concluded that H12A, H12B, H12C, and H12D, H13A, H13B, H13C, and H13D are supported, and technological advances have an affirmative and significant effect mediation between exogenous variables. 
Table 8. Moderation analysis.

\begin{tabular}{|c|c|c|c|c|c|c|c|c|}
\hline Hypotheses & Moderator & Moderation & Coefficient & SE & $\mathbf{T}$ & $p^{*}$ & LLCI & ULCI \\
\hline \multicolumn{9}{|c|}{ Moderating Effect of TEA b/w PES and Firm's operational performance (OP) } \\
\hline H11A: & TEA & PES $\times$ TEA & -0.0603 & 0.0126 & -4.80 & 0.0000 & -0.0849 & -0.0357 \\
\hline \multicolumn{9}{|c|}{ Moderating Effect of TEC b/w POP and Firm's operational performance (OP) } \\
\hline H11B: & TEA & POP $\times$ TEA & -0.1433 & 0.0148 & -9.66 & 0.0000 & -0.1724 & -0.1142 \\
\hline \multicolumn{9}{|c|}{ Moderating Effect of TEA b/w OPR and Firm's operational performance (OP) } \\
\hline H11C: & TEA & OPR $\times$ TEA & -0.1471 & 0.0142 & -10.36 & 0.0000 & -0.1750 & -0.1193 \\
\hline \multicolumn{9}{|c|}{ Moderating Effect of TEA b/w CP and Firm's operational performance (OP) } \\
\hline H11D: & TEA & $\mathrm{CP} \times \mathrm{TEA}$ & -0.1774 & 0.0134 & -13.20 & 0.0000 & -0.2038 & -0.1511 \\
\hline \multicolumn{9}{|c|}{ Moderating Effect of TEA b/w PES and Firm's financial performance (FP) } \\
\hline H12A: & TEA & $\mathrm{PEP} \times \mathrm{TEA}$ & -0.1124 & 0.0133 & -8.45 & 0.0000 & -0.1386 & -0.0863 \\
\hline \multicolumn{9}{|c|}{ Moderating Effect of TEA b/w POP and Firm's financial performance (FP) } \\
\hline H12B: & TEA & $\mathrm{POP} \times \mathrm{TEA}$ & -0.0289 & 0.0108 & -2.67 & 0.0076 & -0.0500 & -0.0077 \\
\hline \multicolumn{9}{|c|}{ Moderating Effect of TEA b/w OPR and Firm's financial performance (FP) } \\
\hline H12C: & TEA & OPR $\times$ TEA & -0.0525 & 0.0116 & -4.51 & 0.0000 & -0.0753 & -0.0297 \\
\hline \multicolumn{9}{|c|}{ Moderating Effect of TEA b/w CP and Firm's financial performance (FP) } \\
\hline H12D: & TEA & $\mathrm{CP} \times \mathrm{TEC}$ & -0.0535 & 0.0115 & -4.67 & 0.0000 & -0.0760 & -0.0311 \\
\hline
\end{tabular}

' $x$ ' denotes the multiplicative sign; * indicates rejection of Null Hypotheses at $p<0.05 ; \mathrm{OP}=$ Operational performance; FP = Financial performance; $\mathrm{PES}=$ Proactive environmental strategy; $\mathrm{POP}=$ Planning and Organizational practices; $\mathrm{CP}=\mathrm{Communicational}$ practices; OPR = Operational practices; and TEA = Technological advances.

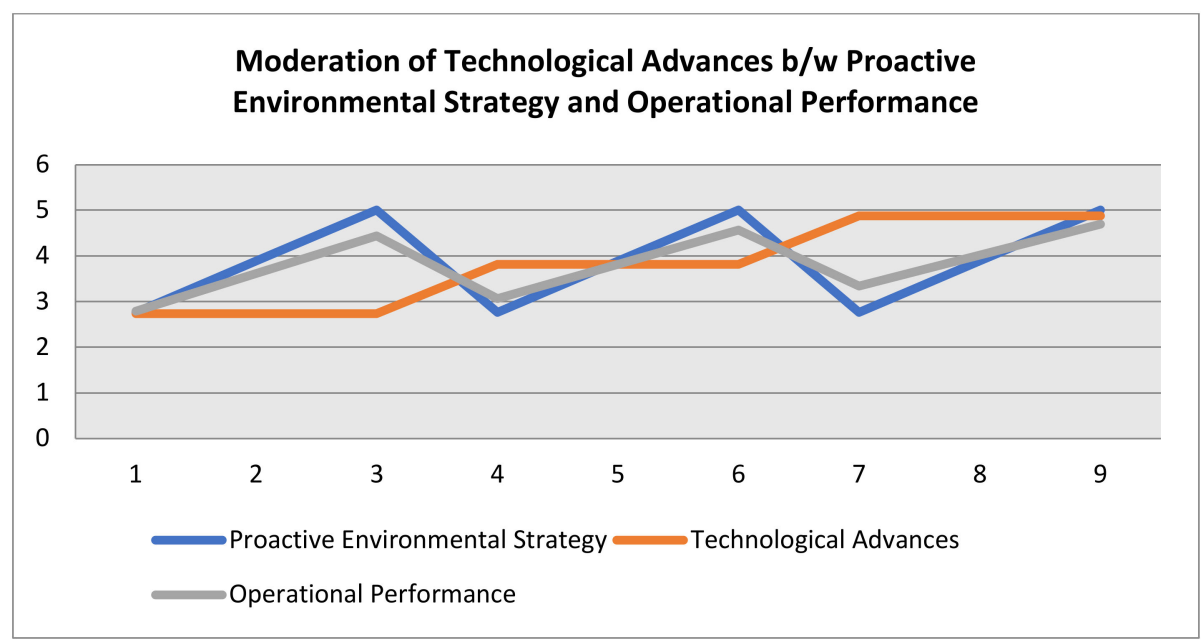

Figure 11. Moderation of Technological Advances between Proactive Environmental Strategy and Operational Performance. Source: Authors' calculation. 


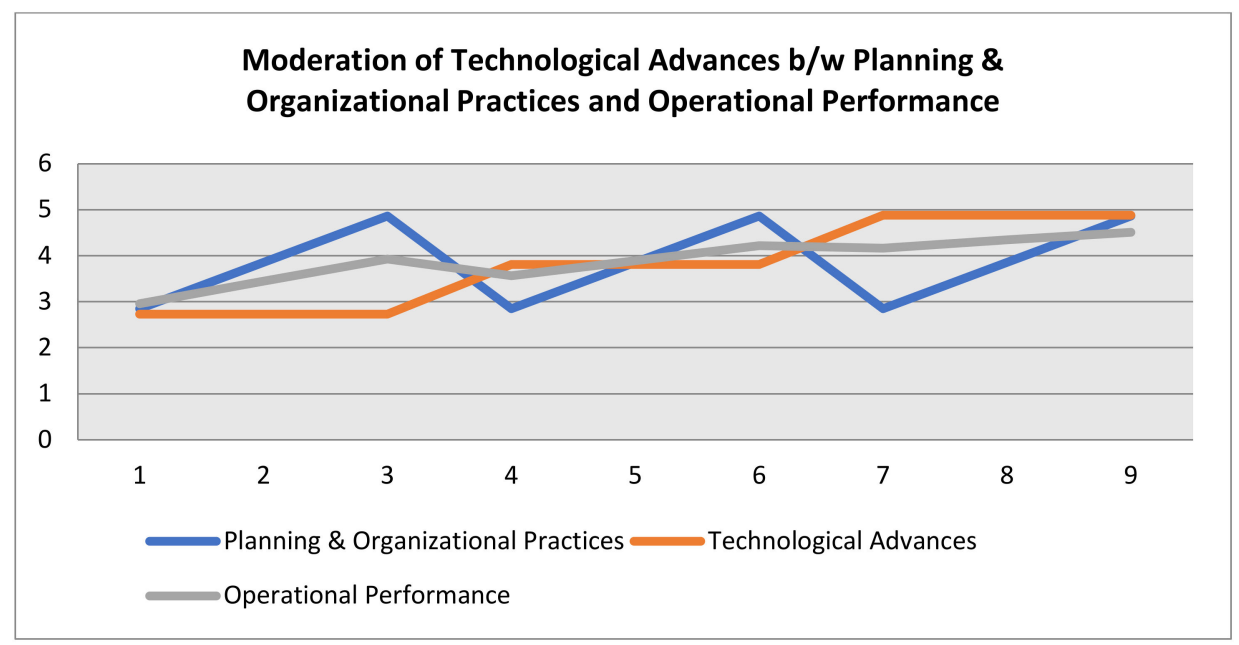

Figure 12. Moderation of Technological Advances between Planning and Organizational practices and Operational Performance. Source: Authors' calculation.

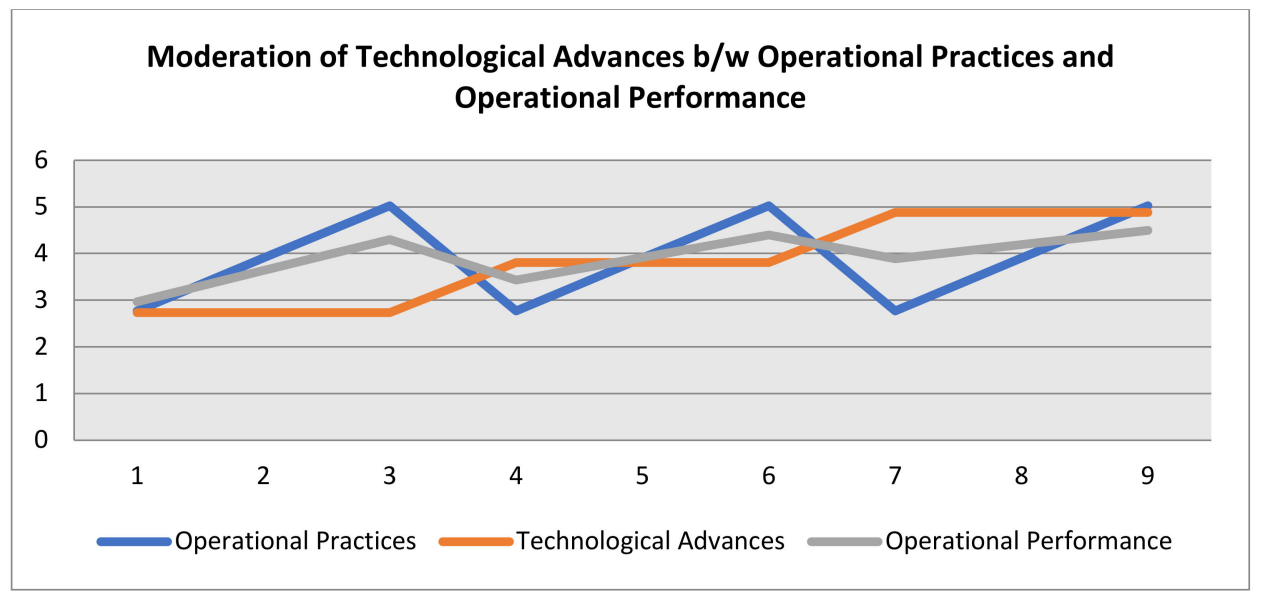

Figure 13. Moderation of Technological Advances between Operational practices and Operational Performance. Source: Authors' calculation.

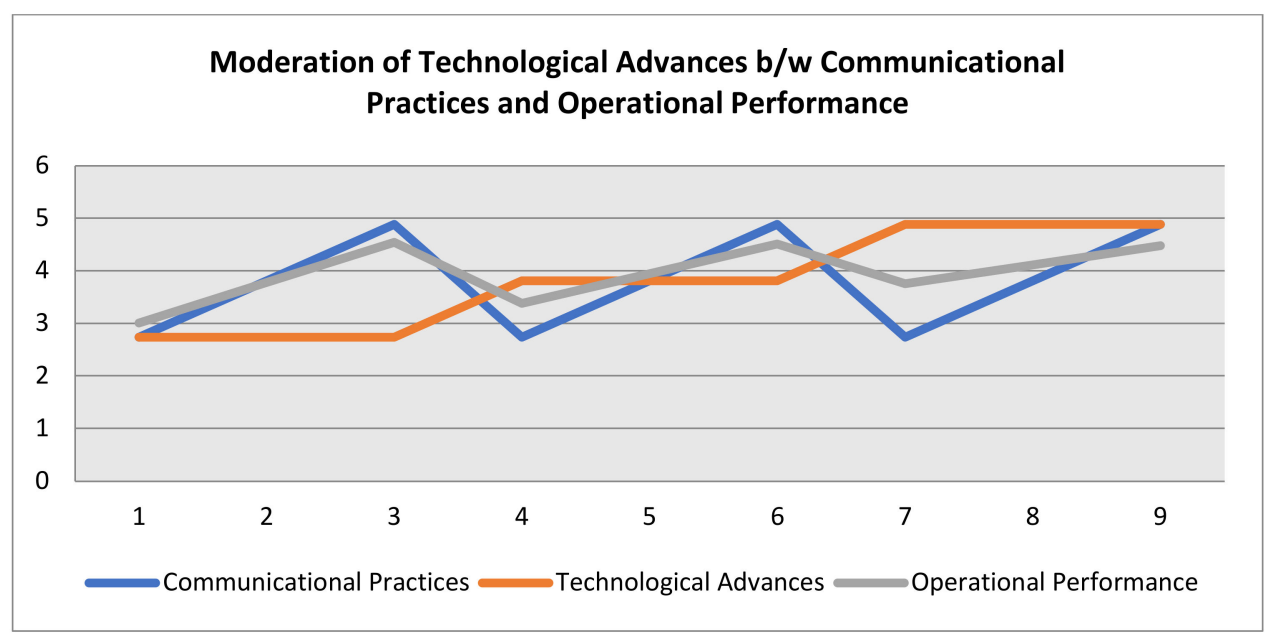

Figure 14. Moderation of Technological Advances between Communicational practices and Operational Performance. Source: Authors' calculation. 


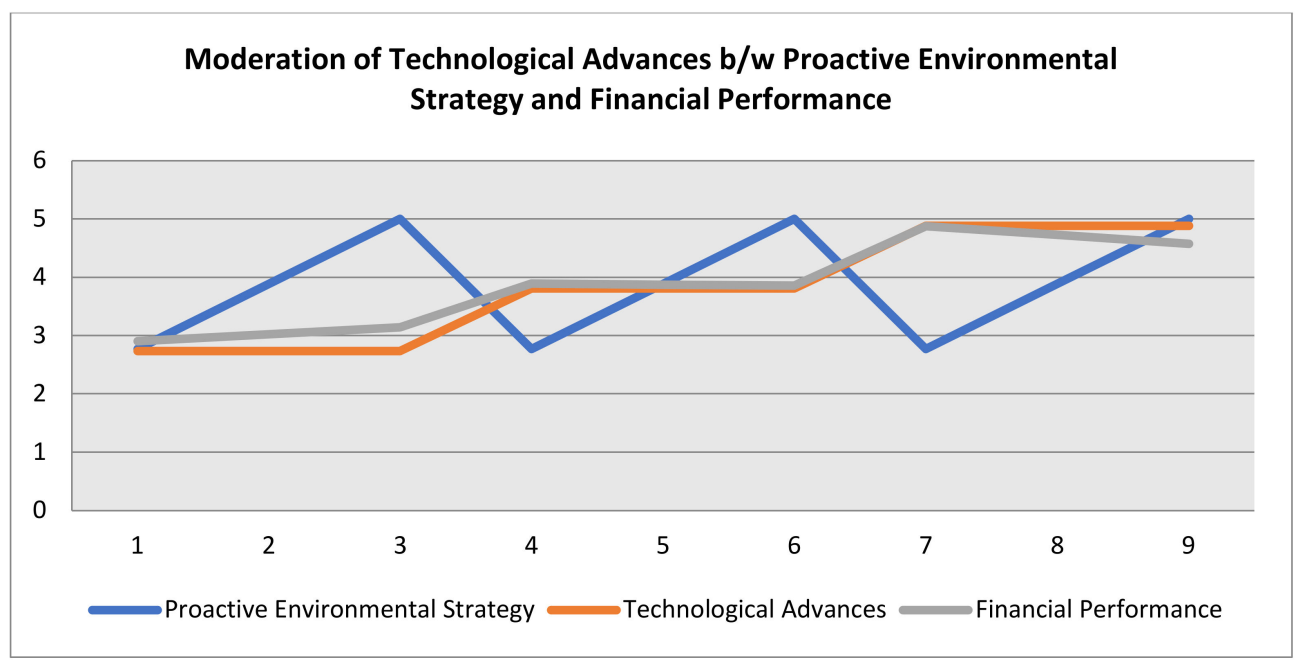

Figure 15. Moderation of Technological Advances between Proactive Environmental Strategy and Financial Performance. Source: Authors' calculation.

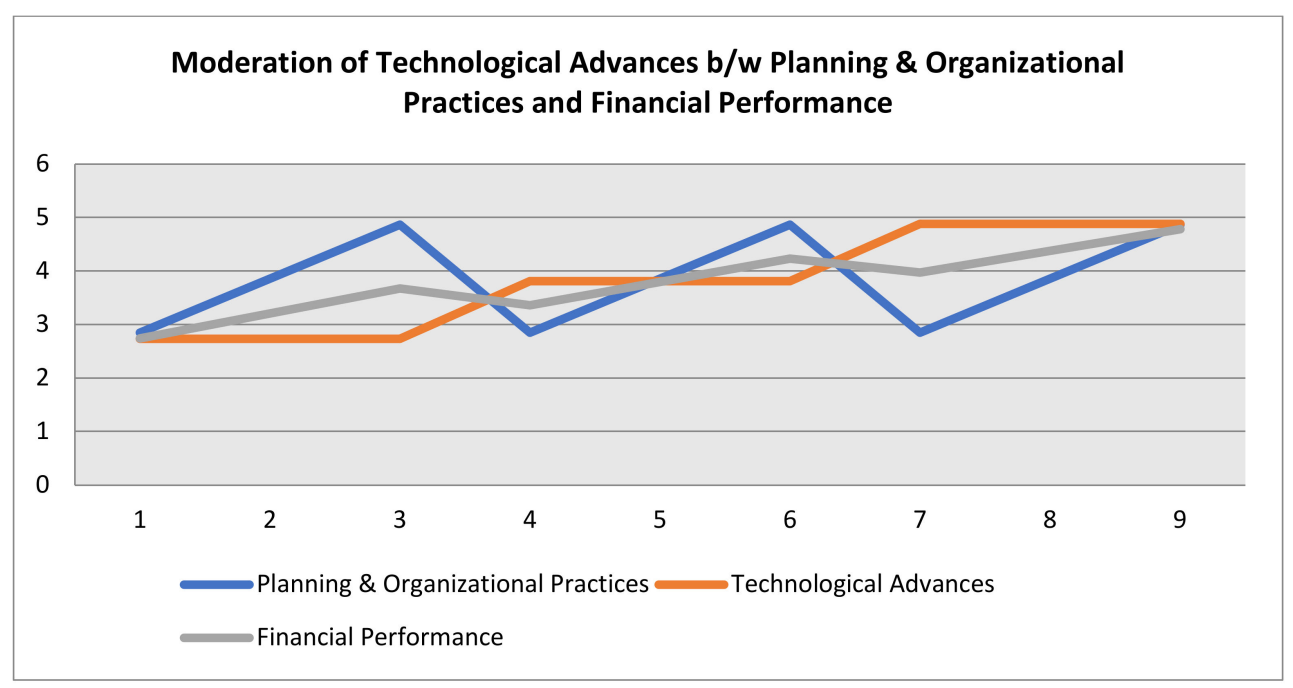

Figure 16. Moderation of Technological Advances between Planning and Organizational practices and Financial Performance. Source: Authors' calculation.

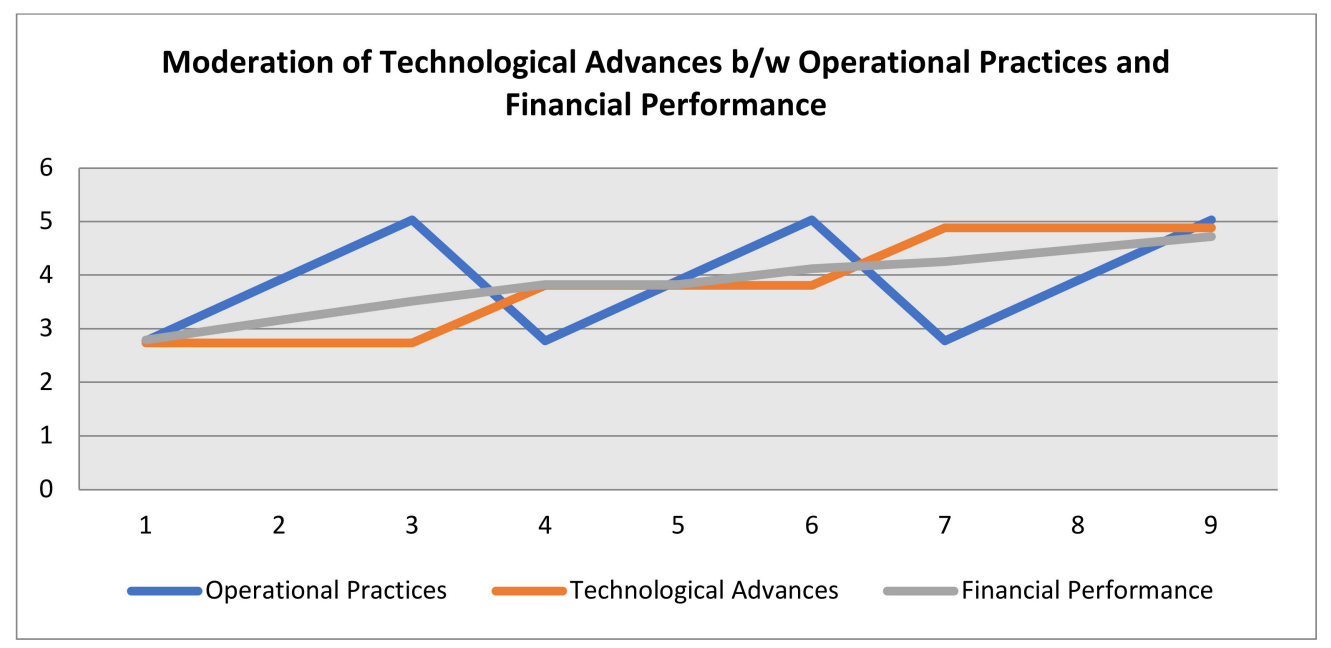

Figure 17. Moderation of Technological Advances between Operational practices and financial performance. Source: Authors' calculation. 


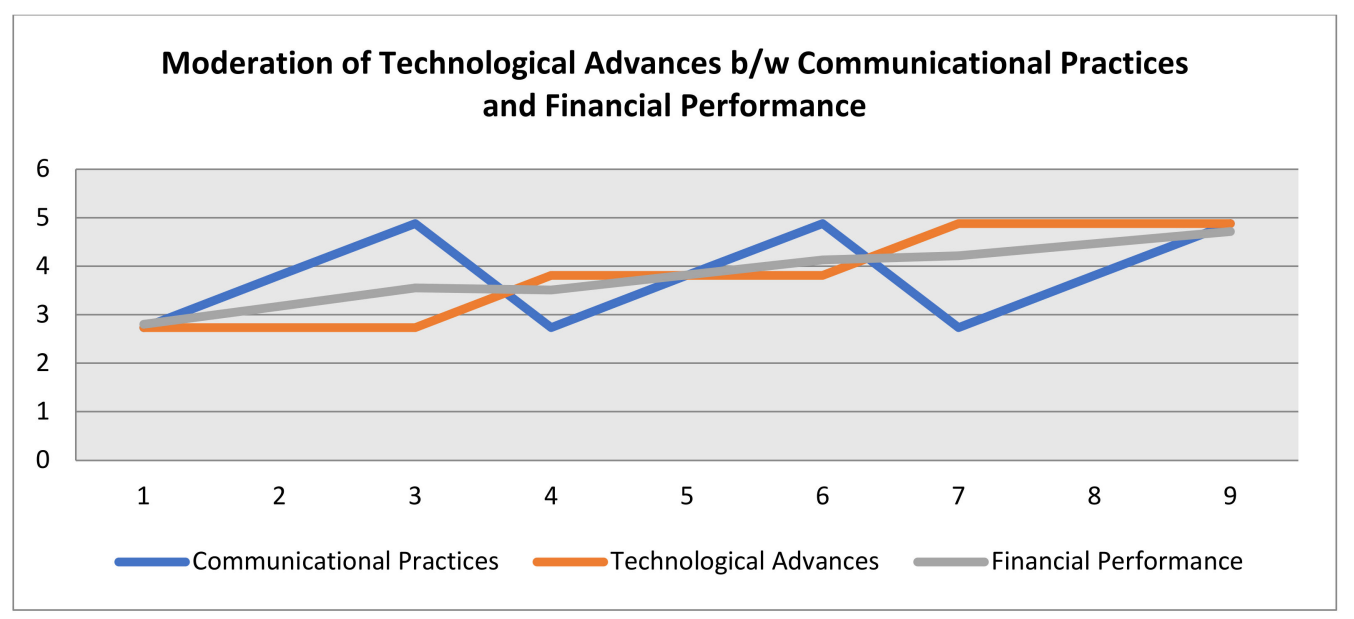

Figure 18. Moderation of Technological Advances between Communicational practices and Financial Performance. Source: Authors' calculation.

\section{Discussion}

The undertaken study exhibited that the proactive environmental strategy positively and significantly impacts the financial and operational performances. The previous studies also demonstrated similar results, such as $[1,5,12,17,19,23-25,42,56-58]$. The outcomes further suggested that the three determinants of proactive environmental strategy, such as planning and organizational practices and communicational and operational practices, have an affirmative and significant influence on operational and financial performance. Previous literature also demonstrated similar outcomes [5,12,17-20,22,24,59]. Moreover, the study outcomes concluded that operational performance has an affirmative and significant influence on financial performance. These outcomes align with the previous literature $[2,15,23,35,60]$. The findings also demonstrated that eco-innovation has an affirmative and cogent influence on mediation in the association of proactive environmental strategy and its determinants, for instance, planning and organizational practices, operational practices, and communicational practices on the operational and financial performance. The previous literature also demonstrated that eco-innovation has an affirmative and cogent mediation in an association of proactive environmental strategy and its determinants on the operational and financial performance $[14,27-30,32,61,63,64]$. The findings confirmed that technological advances have a compelling influence on moderation in a proactive environmental strategy and its determinants, such as planning and organizational practices, communicational and operational practices on operational and financial performance. The findings of previous studies are aligned with the outcomes of the undertaken study, such as $[2,31,33,42,56,66-71]$.

\section{Conclusions}

The findings of the direct relationship concluded that the proactive environmental strategy positively and significantly impacts the financial and operational performances. It means proactive environmental strategy may enhance an organization's operational and financial performance, distinguishing the firm from rival companies and acquiring a sustainable competitive advantage. The outcomes further concluded that the three determinants of proactive environmental strategy, such as planning and organizational practices, communicational practices, and operational practices, have an affirmative and significant influence on operational and financial performance. Thus, planning and organizational practices may boost the organizational financial and operational performance. Similarly, communicational and operational strategies can enhance the organizational performance imperative for long-term sustainable competitive advantage. The findings also concluded that eco-innovation has an affirmative and cogent influence on mediation in the association of proactive environmental strategy and its determinants, for instance, planning 
and organizational practices, operational practices, and communicational practices on the operational and financial performance. Hence, eco-innovation could be an efficient and effective strategy for a firm's long-term growth and competitive advantage. Finally, the findings confirmed that technological advances have a compelling influence on moderation in a relationship of proactive environmental strategy and its determinants, for instance, planning and organizational practices and communicational and operational practices on the operational and financial performance. Thus, new technologies can boost a firm's financial and operational performance. The overall findings of this research concluded that the incorporated modified model has proven its effectiveness, and could be used for effective management, environmental, and marketing strategies for an organization's competitive and profitable performance.

\subsection{Theoretical and Managerial Implications}

This research's findings provide imperative theoretical implications, such as results enhancing the body of existing knowledge regarding the proactive environmental strategy model regarding the financial and operational performances. Future researchers can also replicate similar models in other industries with the moderation of technological advances and eco-innovation mediation. The practitioners of CSR and higher management of the organizations can make effective CSR and green strategies for competitive advantage and sustainable development in light of the study's outcomes. The government and regulators can devise vigilant strategies and regulations to minimize pollutions and other environmental hazards. Therefore, the undertaken studies demonstrated and concurrently ascertained towards sustainable development of ecological and economic leaders. The practical implications are equally important for every stakeholder, such as the community, policymakers, companies, and regulatory agencies concerned with fostering eco-friendly controlling exercises.

\subsection{Limitations and Potential Areas of Future Studies}

The undertaken study has specific limitations; for instance, we did not analyze the cause and effect between the variables. Thus, it is recommended that future researchers employ more robust models, which may also evaluate the cause and effect between the variables. The current study has incorporated limited independent factors as a proactive environmental strategy; therefore, future studies may incorporate more generalizable and robust results. Several other mediating and moderating factors can be incorporated in future studies for better environmental strategies. The undertaken study has taken only the pharmaceutical sector. Thus, the results cannot be generalizable to other sectors; hence, it is recommended that future studies incorporate multiple sectors for more generalizable outcomes.

Supplementary Materials: The following are available online at https://www.mdpi.com/article/10 .3390/su13169479/s1, Figure S1: Demographic analysis, Figure S2: Descriptive statistics, Figure S3: Reliabilities \& validities, Figure S4: KMO \& Bartlett's analysis, Figure S5: Total Variance explained, Figure S6: Fit-indices measurement, Figure S7: Postulated direct relationship, Figure S8: Mediation analysis through Bootstrapping, Figure S9: Mediation through Normal theory method, and Figures S10-S17: Moderation Analysis of Technological Advances between Exogenous \& endogenous variables. Table S1: Demographic analysis, Table S2: Descriptive statistics, Table S3: Reliabilities \& validities, Table S4: KMO \& Bartlett's analysis, Table S5: Total Variance explained, Table S6: Postulated direct relationship, Table S7: Mediation analysis, Table S8: Moderation analysis.

Author Contributions: Conceptualization, R.R.A. and D.S.; methodology, R.R.A. and D.S. investigation, G.L.K. and J.S.; formal analysis, R.R.A. and D.S.; resources, G.L.K. writing-original draft preparation, D.S. and R.R.A.; writing-review and editing, D.S. and G.L.K.; visualization, J.S.; validation, J.S., supervision, D.S. and J.S.; and funding acquisition, G.L.K. All authors have read and agreed to the published version of the manuscript.

Funding: This research received no external funding. 
Institutional Review Board Statement: Not applicable.

Informed Consent Statement: Not applicable.

Data Availability Statement: Data is provided in Supplementary Materials.

Conflicts of Interest: The authors declare no conflict of interest.

\section{References}

1. Bluemling, B.; Tai, H.-S.; Choe, H. Boundaries, limits, landscapes, and flows: An analytical framework for boundaries in natural resource management. J. Environ. Manag. 2021, 285, 112129. [CrossRef]

2. Lu, J.; Ren, L.; Zhang, C.; Rong, D.; Ahmed, R.R.; Streimikis, J. Modified Carroll's Pyramid of Corporate Social Responsibility to Enhance Organizational Performance of SMEs Industry. J. Clean. Prod. 2020, 271, 1-18. [CrossRef]

3. Wolf, J. Improving the sustainable development of firms: The role of employees. Bus. Strategy Environ. 2013, 22, 92-108. [CrossRef]

4. Forés, B. Beyond Gathering the 'Low-Hanging Fruit' of Green Technology for Improved Environmental Performance: An Empirical Examination of the Moderating Effects of Proactive Environmental Management and Business Strategies. Sustainability 2019, 11, 6299. [CrossRef]

5. Hunt, C.B.; Auster, E.R. Proactive environmental management: Avoiding the toxic trap. MIT Sloan Manag. Rev. 1990, 31, 7-18.

6. Genç, E.; Benedetto, A.D. A comparison of proactive and reactive environmental strategies in green product innovation. Int. J. Innovat. Sustain. Dev. 2019, 13, 431. [CrossRef]

7. Hart, S.L.; Ahuja, G. Does it pay to be green? An empirical examination of the relationship between emission reduction and firm performance. Bus. Strateg. Environ. 1996, 5, 48-75. [CrossRef]

8. Vithessonthi, C. Corporate ecological sustainability strategy decisions: The role of attitude towards sustainable development. J. Organ. Transform. Soc. Chang. 2009, 6, 49-64. [CrossRef]

9. Quazi, H.A.; Khoo, Y.K.; Tan, C.M.; Wong, P.S. Motivation for ISO 14000 certification: Development of a predictive model. Omega 2001, 29, 525-542. [CrossRef]

10. Wahyudin, D.; Malik, R.S. Teaching Environmental Education for Sustainable Development: Strategies and Challenges. Int. J. Sustain. High. Educ. 2019, 3, 51. [CrossRef]

11. Carballo-Penela, A.; Doménech, J. Managing the carbon footprint of products: The contribution of the method composed of financial statements (MC3). Int. J. Life Cycle Assess. 2010, 15, 962-969. [CrossRef]

12. Wahba, H. Does the market value corporate environmental responsibility? An empirical examination. Corp. Soc. Resp. Env. Manag. 2008, 15, 89-99. [CrossRef]

13. Aragón-Correa, J.A.; Sharma, S. A contingent resource-based view of proactive corporate environmental strategy. Acad. Manag. Rev. 2003, 28, 71-88. [CrossRef]

14. Seroka-Stolka, O.; Fijorek, K. Enhancing corporate sustainable development: Proactive environmental strategy, stakeholder pressure and the moderating effect of firm size. Bus. Strategy Environ. 2020, 29, 2338-2354. [CrossRef]

15. Min, B.H.; Oh, Y. How Do Performance Gaps Affect Improvement in Organizational Performance? Exploring the Mediating Roles of Proactive Activities. Public Perform. Manag. Rev. 2020, 43, 766-789. [CrossRef]

16. Seid, M. The Veer from Frontier Economics to Eco-Development Paradigm: Approaches, Policies and Strategies of Sustainable Development-The Case of Environmental Governance in Ethiopia. J. Environ. Chem. 2019, 4, 21. [CrossRef]

17. Sharma, P.; Sharma, S. Drivers of proactive environmental strategy in family firms. Bus. Ethics. Q. 2011, 21, 309-334. [CrossRef]

18. Lince, Y.A. Determinants of Environmental Performance with the Carbon Management Strategy as an Intervening Variable. J. Eco. Sustain. Dev. 2019, 10, 60-71.

19. Sharma, S. Managerial interpretations and organizational context as predictors of corporate choice of environmental strategy. Acad. Manag. J. 2000, 43, 681-697. [CrossRef]

20. Buysse, K.; Verbeke, A. Proactive environmental strategies: A stakeholder management perspective. Strateg. Manag. J. 2003, 24, 453-470. [CrossRef]

21. Henriques, I.; Sadorsky, P. The relationship between environmental commitment and managerial perceptions of stakeholder importance. Acad. Manag. J. 1999, 42, 87-99. [CrossRef]

22. Lucas, M.T. Understanding environmental management practices: Integrating views from strategic management and ecological economics. Bus. Strateg. Environ. 2000, 19, 543-556. [CrossRef]

23. González-Benito, J.; González-Benito, O. Environmental proactivity and business performance: An empirical analysis. Omega 2005, 33, 1-15. [CrossRef]

24. González-Benito, J.; González-Benito, Ó. A review of determinant factors of environmental proactivity. Bus. Strateg. Environ. 2006, 15, 87-102. [CrossRef]

25. Koirala, B.S.; Pradhan, G. Determinants of sustainable development: Evidence from 12 Asian countries. Sustain. Dev. 2020, 28, 39-45. [CrossRef]

26. Sangle, S. Empirical analysis of determinants of adoption of proactive environmental strategies in India. Bus. Strategy Environ. 2010, 19, 51-63. [CrossRef]

27. Aldieri, L.; Bruno, B.; Senatore, L.; Vinci, C.P. The future of pharmaceuticals industry within the triad: The role of knowledge spillovers in innovation process. Futures 2020, 122, 102600. [CrossRef] 
28. Liu, J.; Shu, C. Proactive Environmental Strategy, Corporate Venturing, and Firm Performance. Acad. Manag. Proc. 2020,1 , 19394. [CrossRef]

29. Molina-Azorín, J.F.; Claver-Cortés, E.; López-Gamero, M.D.; Tarí, J.J. Green management and financial performance: A literature review. Manag. Decis. 2009, 47, 1080-1100. [CrossRef]

30. Blanco, E.; Rey-Maquieira, J.; Lozano, J. Economic incentives for tourism firms to undertake voluntary environmental management. Tour. Manag. 2009, 30, 112-122. [CrossRef]

31. Son, D.-J.; Kim, C.-S.; Park, J.-W.; Lee, S.-H.; Chung, H.-M.; Jeong, D.-H. Spatial variation of pharmaceuticals in the unit processes of full-scale municipal wastewater treatment plants in Korea. J. Environ. Manag. 2021, 286, 112150. [CrossRef]

32. Delmas, M.; Hoffman, V.H.; Kuss, M. Under the tip of the iceberg: Absorptive capacity, environmental strategy and competitive advantage. Bus. Soc. 2011, 50, 116-154. [CrossRef]

33. Do, B.; Nguyen, N. The Links between Proactive Environmental Strategy, Competitive Advantages and Firm Performance: An Empirical Study in Vietnam. Sustainability 2020, 12, 4962. [CrossRef]

34. Hoang, T.C.; Black, M.C.; Knuteson, S.L.; Roberts, A.P. Environmental Pollution, Management, and Sustainable Development: Strategies for Vietnam and Other Developing Countries. Environ. Manag. 2019, 63, 433-436. [CrossRef] [PubMed]

35. Cheng, C.C.J.; Yang, C.L.; Sheu, C. The link between eco-innovation and business performance: A Taiwanese industry context. J. Clean. Prod. 2014, 64, 81-90. [CrossRef]

36. Hsiao, C.-H.; Wang, F.-J. Proactive personality and job performance of athletic coaches: Organizational citizenship behavior as mediator. Palgrave Commun. 2020, 6, 1-8. [CrossRef]

37. Carballo-Penela, A.; Castromán-Diz, J.L. Environmental Policies for Sustainable Development: An Analysis of the Drivers of Proactive Environmental Strategies in the Service Sector. Bus. Strateg. Environ. 2015, 24, 802-818. [CrossRef]

38. Deutz, P.; Ioppolo, G. From Theory to Practice: Enhancing the Potential Policy Impact of Industrial Ecology. Sustainability 2015, 7 , 2259-2273. [CrossRef]

39. Bansal, P.; Roth, K. Why companies go green: A model of ecological responsiveness. Acad. Manag. J. 2000, 43, 717-736. [CrossRef]

40. Ogueke, N.V.; Emekwuru, N. Regulation of Nanorefrigerant Use: A Proactive Measure Against Possible Undesirable Health and Environmental Implications. Eur. J. Sustain. Dev. Res. 2017, 1, 1-13. [CrossRef]

41. Hart, S.L.; Dowell, G. Invited editorial: A natural-resource-based view of the firm fifteen years after. J. Manag. 2011, 37, 1464-1479. [CrossRef]

42. Hart, S.L. Natural-resource-based view of the firm. Acad. Manag. Rev. 1995, 20, 986-1014. [CrossRef]

43. Oltra, V. Environmental Innovation and Industrial Dynamics: The Contributions of Evolutionary Economics. Working Papers of GREThA, (28). 2008. Available online: http://ideas.repec.org/p/grt/wpegrt/2008--28.html (accessed on 10 October 2020).

44. Rennings, K. Redefining innovation-Eco-innovation research and the contribution from ecological economics. Ecol. Econ. 2000, 32, 319-332. [CrossRef]

45. Rehfeld, K.M.; Rennings, K.; Ziegler, A. Integrated product policy and environmental product innovations: An empirical analysis. Ecol. Econ. 2007, 61, 91-100. [CrossRef]

46. Horbach, J. Determinants of environmental innovation-New evidence from German panel data sources. Res. Policy 2008, 37, 163-173. [CrossRef]

47. Triguero, A.; Moreno-Mondéjar, L.; Davia, M.A. Drivers of different types of eco-innovation in European SMEs. Ecol. Econ. 2013, 92, 25-33. [CrossRef]

48. Weng, H.H.R.; Chen, J.S.; Chen, P.C. Effects of Green Innovation on Environmental and Corporate Performance: A Stakeholder Perspective. Sustainability 2015, 7, 4997-5026. [CrossRef]

49. Li, Y. Environmental innovation practices and performance: Moderating effect of resource commitment. J. Clean. Prod. 2014, 66, 450-458. [CrossRef]

50. De Marchi, V. Environmental innovation and RandD cooperation: Empirical evidence from Spanish manufacturing firms. Res. Policy 2012, 41, 614-623. [CrossRef]

51. Chen, Y.S. The driver of green innovation and green image-Green core competence. J. Bus. Ethics 2008, 81, 531-543. [CrossRef]

52. Del Río, P.; Peñasco, C.; Romero-Jordán, R. What drives eco-innovators? A critical review of the empirical literature based on econometric methods. J. Clean. Prod. 2016, 112, 2158-2170. [CrossRef]

53. Sturiale, L.; Scuderi, A.; Timpanaro, G.; Matarazzo, B. Sustainable Use and Conservation of the Environmental Resources of the Etna Park (UNESCO Heritage): Evaluation Model Supporting Sustainable Local Development Strategies. Sustainability 2020, 12, 1453. [CrossRef]

54. Yarahmadi, M.; Higgins, P.G. Motivations towards environmental innovation: A conceptual framework for multiparty cooperation. Eur. J. Innov. Manag. 2012, 15, 400-420. [CrossRef]

55. Deng, W. Sustainable development: Impacts of consumers' risk aversion on remanufacturing model selection and environmental performance. Sustain. Dev. 2020, 28, 1564-1574. [CrossRef]

56. Menguc, B.; Ozanne, L.K. Challenges of the "green imperative": A natural resource-based approach to the environmental orientation-business performance relationship. J. Bus. Res. 2005, 58, 430-438. [CrossRef]

57. Clarkson, P.; Li, Y.; Richardson, G.; Vasvari, F. Does it really pay to be green? Determinants and consequences of proactive environmental strategies. J. Account. Public Policy 2011, 30, 122-144. [CrossRef] 
58. Ghisetti, C.; Rennings, K. Environmental innovations and profitability: How does it pay to be green? An empirical analysis on the German innovation survey. J. Clean. Prod. 2014, 75, 106-117. [CrossRef]

59. Roome, N. Developing environmental management systems. Bus. Strategy Environ. 1992, 1, 11-24. [CrossRef]

60. Chi, C.G.; Gursoy, D. Employee satisfaction, customer satisfaction, and financial performance: An empirical examination. Int. J. Hosp. Manag. 2009, 28, 245-253. [CrossRef]

61. Fussler, C.; James, P. Driving Eco-Innovation: A Breakthrough Discipline for Innovation and Sustainability; Pitman Publishing: London, UK, 1996.

62. Ciasullo, M.V.; Manna, R.; Cavallone, M.; Palumbo, R. Envisioning the future of health systems: Exploratory insights from European countries. Futures 2020, 121, 102585. [CrossRef]

63. Kemp, R.; Pearson, P. Final Report MEI Project about Measuring Eco-Innovation, Maastricht. 2008. Available online: http: / / www.oecd.org/env / consumption-innovation/43960830.pdf (accessed on 5 October 2020).

64. European Commission. Communication from the Commission to the European Parliament, the Council, the European Economic and Social Committee and the Committee of the Regions. Innovation for a Sustainable Future-The Eco-Innovation Action Plan (Eco-AP). 2011. Available online: http:/ / eur-lex.europa.eu/legal-content/EN/TXT/?uri=CELEX\%3A52011DC0899 (accessed on 25 September 2020).

65. Wagner, M. How to reconcile environmental and economic performance to improve corporate sustainability: Corporate environmental strategies in the European paper industry. J. Environ. Manag. 2005, 76, 105-118. [CrossRef]

66. OECD. Sustainable Manufacturing and Eco-Innovation. Framework, Practices and Measurement. 2009. Available online: http:/ / www.oecd.org/innovation/inno/43423689.pdf (accessed on 20 October 2020).

67. Ioppolo, G.; Cucurachi, S.; Salomone, R.; Saija, G.; Ciraolo, L. Industrial ecology and environmental lean management: Lights and shadows. Sustainability 2014, 6, 6362-6376. [CrossRef]

68. Ziegler, A.; Nogareda, J.S. Environmental management systems and technological environmental innovations: Exploring the causal relationship. Res. Policy 2009, 38, 885-893. [CrossRef]

69. Watson, K.; Klingenberg, B.; Polito, T.; Geurts, T. Impact of environmental management system implementation on financial performance. Manag. Environ. Qual. 2004, 15, 622-628. [CrossRef]

70. Liu, X.; Liu, B.; Shishime, T.; Yu, Q.; Bi, J.; Fujitsuka, T. An empirical study on the driving mechanism of proactive corporate environmental management in China. J. Environ. Manag. 2010, 91, 1707-1717. [CrossRef] [PubMed]

71. Li, Y.; Wang, L.; Liu, Y. Organisational learning, product quality and performance: The moderating effect of social ties in Chinese cross-border outsourcing. Int. J. Prod. Res. 2011, 49, 159-182. [CrossRef]

72. Salvadó, J.A.; de Castro, G.M.; López, J.E.N.; Verde, M.D. Environmental Innovation and Firm Performance. A Natural Resource-Based View; Palgrave Macmillan: Basingstoke, UK, 2012.

73. Wang, Z.; Wang, N. Knowledge sharing, innovation and firm performance. Expert Syst. Appl. 2012, 39, 8899-8908. [CrossRef]

74. Emory, C.W.; Cooper, D.R. Business Research Methods, 4th ed.; Richard D Irwin: Homewood, IL, USA, 1991.

75. Byrne, B.M. Structural Equation Modeling with AMOS, Basic Concepts, Application and Programming, 2nd ed.; La Erlbaum Associates: Trenton, NJ, USA, 2009.

76. Huang, J.H.; Lee, B.C.Y.; Ho, S.H. Consumer attitude toward grey market goods. Int. Mark. Rev. 2004, 21, 598-614. [CrossRef]

77. Hair, J.F.; Hult, G.T.M.; Ringle, C.M.; Sarstedt, M. A Primer on Partial Least Squares Structural Equation Modeling; Sage: Thousand Oaks, CA, USA, 2017. [CrossRef]

78. Fornell, C.; Larcker, D.F. Evaluating structural equation models with unobservable variables and measurement error. J. Mark. Res. 1981, 18, 39-50. [CrossRef]

79. Ahmed, R.R.; Qureshi, J.A.; Štreimikienè, D.; Soomro, R.H.; Vveinhardt, J. Guerrilla marketing trends for sustainable solutions: Evidence from SEM-based multivariate and conditional process approaches. J. Bus. Econ. Manag. 2020, 21, 851-871. [CrossRef]

80. Kaiser, H.F. An index of factorial simplicity. Psychometrika 1974, 39, 31-36. [CrossRef]

81. Hayes, A.F.; Rockwood, N.J. Conditional process analysis: Concepts, computation, and advances in modeling of the contingencies of mechanisms. Am. Behav. Sci. 2020, 64, 19-54. [CrossRef]

82. Sobel, M.E. Some New Results on Indirect Effects and Their Standard Errors in Covariance Structure Models. In Sociological Methodology; Leinhart, S., Ed.; Jossey-Bass: San Francisco, CA, USA, 1986; pp. 159-186. [CrossRef] 